\title{
What's In a Name? That Which We Call Capital Controls
}




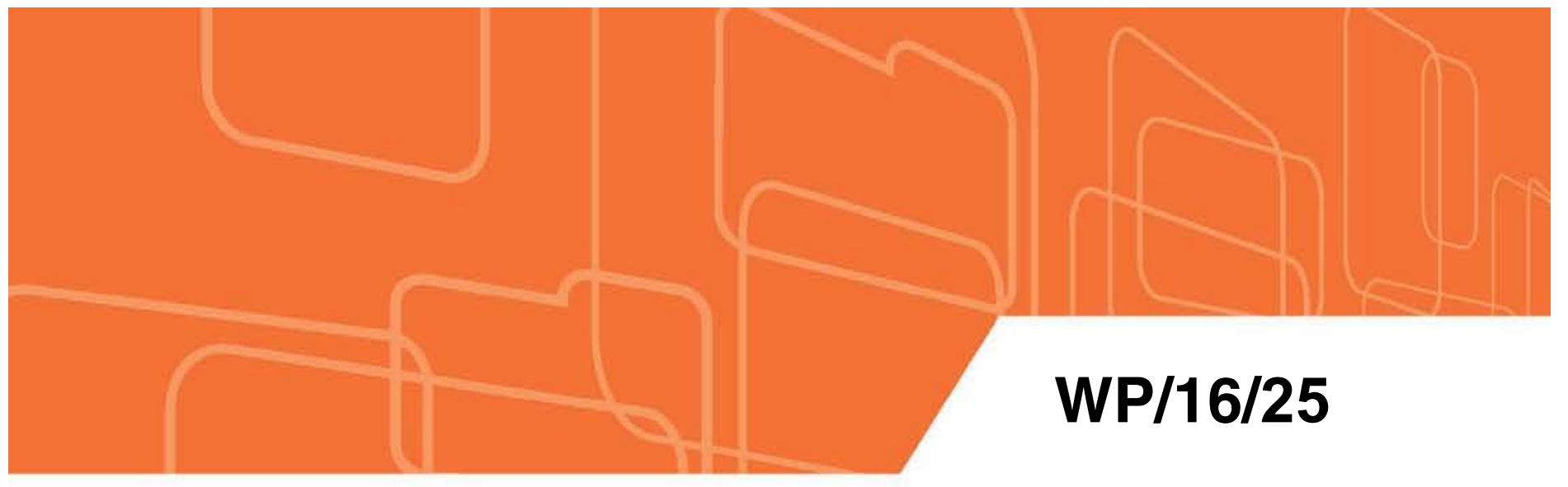

\section{IMF Working Paper}

\section{What's In a Name? That Which We Call Capital Controls}

by Atish R. Ghosh and Mahvash S. Qureshi

I N T E R N A T I O N A L M O N E T A R Y F U N D 


\title{
IMF Working Paper
}

Research Department

\section{What's In a Name? That Which We Call Capital Controls \\ Prepared by Atish R. Ghosh, and Mahvash S. Qureshi ${ }^{\dagger}$}

February 2016

\section{IMF Working Papers describe research in progress by the author(s) and are published to elicit comments and to encourage debate. The views expressed in IMF Working Papers are those of the author(s) and do not necessarily represent the views of the IMF, its Executive Board, or IMF management.}

\begin{abstract}
This paper investigates why controls on capital inflows have a bad name, and evoke such visceral opposition, by tracing how capital controls have been used and perceived, since the late nineteenth century. While advanced countries often employed capital controls to tame speculative inflows during the last century, we conjecture that several factors undermined their subsequent use as prudential tools. First, it appears that inflow controls became inextricably linked with outflow controls. The latter have typically been more pervasive, more stringent, and more linked to autocratic regimes, failed macroeconomic policies, and financial crisis - inflow controls are thus damned by this "guilt by association." Second, capital account restrictions often tend to be associated with current account restrictions. As countries aspired to achieve greater trade integration, capital controls came to be viewed as incompatible with free trade. Third, as policy activism of the 1970s gave way to the free market ideology of the 1980s and 1990s, the use of capital controls, even on inflows and for prudential purposes, fell into disrepute.
\end{abstract}

JEL Classification Numbers: F21, F32, F38

Keywords: capital controls, capital flows, gold standard, interwar period, Bretton Woods

Authors’ E-Mail Addresses: aghosh@,imf.org; mqureshi@imf.org

\footnotetext{
$\dagger$ We thank Eric Helleiner, together with Chikako Baba, Anna Maria Kokenyne, Nadia Rendak, and other IMF colleagues, as well as seminar participants at the Graduate Institute of International and Development Studies, Geneva, and the NIPFP-DEA Research Program, New Delhi, for many helpful comments and suggestions. We are grateful to Eun Sun Jang for excellent research assistance. The views expressed herein, and any errors, are our own responsibility.
} 
Contents

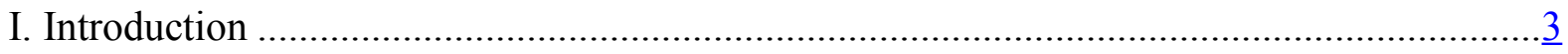

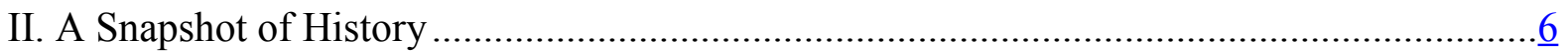

A. The Golden Era of Financial Globalization ........................................................ 7

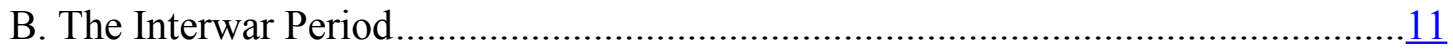

C. The Bretton Woods Era...................................................................................

D. Advent of Floating and the Washington Consensus ......................................... 22

E. The Global Financial Crisis and its Aftermath..............................................

III. Unraveling the Thinking Behind Inflow Controls ...................................................

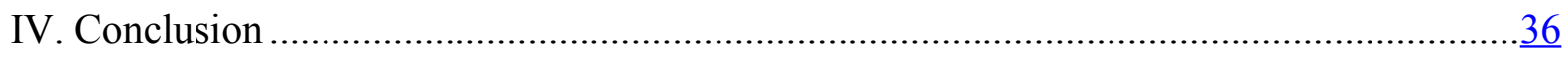

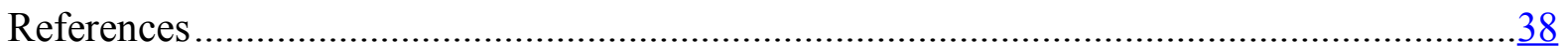

Tables

Table 1. Long-term Publicly Issued Capital Investment Stock, 1914 .................................10

Table 2. Selected Cases of Inflow Controls Tightening in Advanced Economies ..................20

Table 3. Selected Cases of Inflow Controls Tightening in Emerging Markets .....................29

Table 4. Selected Cases of Post-Global Financial Crisis Measures to Limit Capital Inflows $\underline{32}$

Figures

Figure 1. Net Capital Flows, 1860-1913 ................................................................................. 8

Figure 2. Rise and Fall of the Interwar Gold Standard .............................................

Figure 3. Net Capital Flows to Selected Countries, 1923-44 ..........................................12

Figure 4. Exchange Restrictions and Abandoning of Gold Standard, 1931-32 .....................13

Figure 5. United States' Balance of Payments, 1919-39 ................................................15

Figure 6. Capital Controls in Advanced and Emerging Market Economies, 1950-2010 ........17

Figure 7. Net Capital Flows to Selected Countries, 1950-73 ...........................................21

Figure 8. Net Capital Flows to Emerging Markets by Type of Flow, 1970-2013 ..................26

Figure 9. Net Capital Flows to Emerging Markets, 2000Q1-2013Q4 ................................. $\underline{30}$

Figure 10. Capital Controls and Polity, 1950-2010 .......................................................

Figure 11. Foreign Currency-Related Prudential Measures in Emerging Markets ................. $\underline{36}$ 


\section{INTRODUCTION}

"I have only eight seconds left to talk about capital controls. But that's OK. I don't need more time than that to tell you: they don't work, I wouldn't use them, I wouldn't recommend them..."

Agustin Carstens ${ }^{1}$

Governor, Bank of Mexico

Capital controls have a bad name. While their potential usefulness for managing the risks associated with capital inflows has gained greater recognition in recent years (Ostry et al., 2010, 2011; IMF, 2012a), as the quote above amply demonstrates, they are still viewed with considerable suspicion and deep misgivings over their use. An-oft heard argument against capital controls is that they are subject to evasion and circumvention, yet one never hears the same argument applied to other policy instruments - for instance, that taxes should be abolished because they are subject to evasion. Likewise, despite being very much in vogue since the global financial crisis, the evidence on the effectiveness of macroprudential measures is hardly conclusive. ${ }^{2}$ It is telling, moreover, that even when capital inflow controls are employed, countries often prefer to use euphemisms such as "prudential measures" when referring to them. ${ }^{3}$ This visceral opposition to inflow controls is particularly surprising since such measures were often integral to advanced economies' efforts at managing "hot money" flows as they pursued their own domestic and external financial liberalization in the latter half of the twentieth century. So whence the bad name associated with inflow controls? That is the question we investigate in this paper.

To address this question, we delve into the historical record - tracing both the use of capital controls and how thinking about them has evolved — dating back to the gold standard era. While existing studies have looked at the historical evolution of capital flows and capital account liberalization in general (e.g., Obstfeld and Taylor, 1998, 2003; Quinn, 2003; Schularick, 2006), the use of inflow controls as a policy tool to tame volatile capital flows has not been specifically analyzed from a historical perspective. Yet, modern day calls for capital controls as a preventive and prudential instrument pertain mainly to inflows in the context of largely liberalized capital accounts. To make an informed judgment about their potential use requires a better understanding of the historical practice and nature of restrictions, and the basis for the perceptions (or a change in perceptions) and biases surrounding their use. ${ }^{4}$

\footnotetext{
${ }^{1}$ Remarks made at Rethinking Macro Policy III Conference, Washington DC, April 15, 2015 (http://www.imf.org/external/mmedia/view.aspx?vid=4176918093001).

${ }^{2}$ See, for example, Galati and Moessner (2014).

${ }^{3}$ Yet, as Juliet remarks in Shakespeaker's famous play, Romeo and Juliet (Act II): "What's in a name? That which we call a rose, by any other word would smell as sweet."

${ }^{4}$ A voluminous literature (theoretical and empirical) analyzes the pros and cons of capital account openness, as well as the need and effectiveness of capital controls as a short-term policy tool. See Ostry et al. (2015) for a detailed review. In the political science domain, several studies examine the political economy dimension of financial globalization (e.g., Helleiner, 1994; Kapstein, 1994; Quinn and Inclán, 1997; Abdelal, 2006).
} 
In fact, capital controls - both on inflows and on outflows - have a very long history, with restrictions on the import and export of currency dating back to ancient times. ${ }^{5}$ Even during the late nineteenth century, often considered the golden era of financial globalization, the leading capital exporters of the day (Britain, France, and Germany) at times restricted issuances on their markets, albeit mainly for political than for economic reasons. Likewise, the capital importers of the era restricted inflows mostly for strategic purposes, and out of concerns about "foreign domination." In the interwar period, however, the situation changed and controls on outflows became more widespread - especially among autocratic and authoritarian regimes - as attempts at restoring the pre-World War I liberal international monetary order crumbled after Germany suffered a "sudden stop" in 1931, and imposed exchange restrictions and a payments standstill that triggered a run on the pound sterling (forcing it off the gold standard). What followed was a dizzying decade of destabilizing hot money flows to which countries responded with a variety of exchange controls on outflows, as well as with trade restrictions and competitive devaluations.

In the post-World War II period, as nations collectively attempted to design a new international monetary system, memories of the economic chaos of the interwar period were still fresh. For the principal architects of the Bretton Woods system-John Maynard Keynes and Harry Dexter White - the lesson of the interwar period was that free capital mobility and free trade in goods and services are incompatible: destabilizing capital flows will result in calls for protectionism. Moreover, they recognized that for most countries, capital mobility would undermine the ability of the government to pursue the demand management policies increasingly expected by the electorate, while also maintaining a fixed exchange rate and avoiding competitive devaluations (Helleiner, 1994). ${ }^{6}$ Accordingly, their original drafts of the IMF's Articles envisaged capital controls as a permanent, structural element of the international financial landscape, and - despite successful intervention by powerful New York bankers to water down these provisions - the IMF's Articles of Agreement stress current account convertibility over capital account convertibility.

In the early years of the Bretton Woods era, capital controls thus remained widespreadmore so in advanced economies than in emerging markets, and (much) more so on outflows than on inflows. Inflow restrictions were initially directed mainly at limiting foreign ownership of "strategic" industries, but in later years, prudential measures to restrict speculative flows became more prevalent. Even the original OECD Code of Liberalization of Capital Movements adopted in 1961 explicitly excluded short-term capital flows from liberalization obligations. Liberalization in advanced countries began in the 1970s, gathering

\footnotetext{
${ }^{5}$ Einzig (1970), for example, documents the existence of exchange control policy in Sparta and Egypt under Ptolemaic and Roman rule.

${ }^{6}$ This is akin to viewing the evolution of capital controls in the framework of the macroeconomic policy "trilemma" or the "impossible trinity" of fixed exchange rate regimes, monetary policy autonomy, and full capital mobility — eloquently demonstrated by Fleming (1962) and Mundell (1963) — with one goal subordinated to the others at different points of time.
} 
pace in the 1980s, as free market ideologies took hold. Increasing internationalization of commercial activity (for instance, in the form of multinational corporations) also militated against capital controls. Moreover, the desire on the part of the United States and the United Kingdom to be global financial centers, and that of European countries for greater regional integration, implied that barriers to capital movements had to be removed.

In emerging markets, the situation was the reverse. Starting from relatively open capital accounts in the immediate post-War period, the trend was toward greater restrictiveness in the late 1960s and early 1970s, as capital account restrictions were adopted to promote inward-looking models of industrialization or, in some cases, as props for poor macroeconomic policies (which typically required outflow restrictions to protect the balance of payments). Not until the 1980s, did these economies begin to liberalize, and although capital account liberalization was not part of the original Washington Consensus (Williamson, 1990), the idea of subjecting government policies to market discipline by eschewing outflow controls was very much in the spirit of that creed. Yet, though the impetus was nearly always to liberalize capital outflows, both outflow and inflow restrictions (even those for prudential purposes) became subject to liberalization efforts. By the eve of the global financial crisis in 2008, active management of inflows had also become discredited and disreputable - so much so that when Thailand tried to rein in capital inflows by imposing a capital control in December 2006, market reaction was sharp and negative, evoking memories of the financial crisis triggered by capital outflows crisis a decade earlier, and forcing the prompt reversal of the measure. Likewise, attempts in the aftermath of the global financial crisis to use inflow controls to tame volatile capital flows have not always been viewed favorably, generating a heated debate both among academics and policy makers.

Our reading of the historical record, based on an extensive collection of information from primary and secondary sources, yields several conjectures why inflow controls evoke such visceral opposition to this day. The simplest explanation is that, in the minds of many, inflow and outflow controls are inextricably linked. Traditionally, the latter were more prevalent, more stringent, and typically associated with autocratic and repressive regimes preventing capital flight; governments trying to prop up failed macroeconomic policies; or financial crisis in which residents lose the real value of their savings, and nonresidents are unable to repatriate their capital. Inflow measures are often damned by this "guilt by association." This is also obvious from some of the criticisms typically leveled against inflow controls, which are actually much more pertinent to outflow controls (for instance, that they are persistent and pervasive; encourage poor macroeconomic policies; and are ineffective). Thus, when countries liberalized their capital accounts and embraced more market friendly policies, they often jettisoned both outflow and inflow controls at the same time, without fully taking into account the prudential role of the latter.

Likewise, capital account restrictions are often associated with current account restrictionsbecause, historically, the most common form of capital control was exchange restrictions that impeded the movement of both goods and capital. As countries liberalized trade under the "Washington Consensus," in contrast to the Keynes-White thesis that viewed capital controls 
as aiding free trade (by reducing protectionist pressures), capital controls came to be viewed as incompatible with free trade. More generally, capital controls became associated with attempts at fine-tuning the economy (since part of their justification is that they give policy autonomy), which itself became discredited after the stagflationary 1970s - paving the way for the free market ideology that was highly prevalent till the global financial crisis. ${ }^{7}$

Inflow controls thus appear to have an undeservedly bad name. While they are not a flawless instrument to manage the macroeconomic and financial-stability risks associated with capital inflows, there is no reason to believe that they are inherently worse or costlier than any other policy measure. Advanced economies relied on inflow controls as their financial markets developed, and in most cases abolished them for reasons that do not necessarily apply to today's emerging markets (such as the desire for greater regional economic integration in Europe). The pros and cons of the use of inflow controls thus need to be assessed in light of the particular circumstances facing the country — and weighed against the costs and benefits of other available policy tools.

The rest of the paper is organized as follows. Section II traces - in broad strokes-basic trends in cross-border capital flows and the adoption of capital controls in major economies since the late nineteenth century, highlighting the key events that shaped thinking about capital controls. Section III elaborates on why inflow controls are often viewed with suspicion. Section IV concludes.

\section{A SNAPShOt OF History}

Managing capital flows is scarcely a new idea: there is evidence, for example, on the existence of exchange controls in ancient times (Einzig, 1970). Restrictions on the import and export of currency into and out of England are documented to have existed in the middle ages, as well as in the early modern period. ${ }^{8}$ As early as 1758 , the Marquis de Mirabeau warns in his treatise, L'Ami des Hommes, against relying on hot money flows that may be fickle and subject to sudden repatriation. ${ }^{9}$

In tracing the modern history of capital controls, however, it is useful to begin with the second half of the nineteenth century - widely considered to be the first wave of financial globalization - and distinguish among five key phases: the pre-World War I period (commonly referred to as the gold standard era); the interwar years (itself divisible into the re-establishment of the gold standard and its subsequent demise); the Bretton Woods era; the adoption of generalized floating; and the aftermath of the global financial crisis.

\footnotetext{
${ }^{7}$ In recent years, inflow controls are sometimes suspected of being used to vitiate multilaterally-warranted external adjustment. This concern, however, is mainly relevant for a handful of large economies—and by itself does not explain why the country contemplating imposing the measure would be reluctant to do so.

${ }^{8}$ Noted by Lord Cromer, former Governor of the Bank of England, in the 1966 Arthur K. Salomon lecture:

"International Capital Markets," delivered at the New York University, and in Einzig (1970).

${ }^{9}$ See Brocard (1902), and Bloomfield (1938).
} 


\section{A. The Golden Era of Financial Globalization}

The period encompassing the latter half of the nineteenth century and the first decades of the twentieth has often been called the heyday of financial globalization - and with good reason. During these years, the major capital exporting countries - Britain, France, and Germanyexported as much as five to ten percent of GDP per year of mainly long-term capital to the developing and "emerging market" economies of the day (Figure 1). Foremost among the capital exporters was Great Britain, both in terms of the volume of lending, and the diversity of countries to which she lent. Whereas Britain's lending in the first half of the nineteenth century had been mostly to European countries, by the latter part of the nineteenth century, her portfolio was more heavily weighted to the Americas (United States, Canada, Argentina), as well as to the empire and dominions, most notably, India (Table 1). ${ }^{10}$

Boom-bust cycles in cross-border lending were already apparent (Figure 1). After rising from less than 2 percent of GDP in 1860 to 8 percent of GDP in 1872, British long-term lending collapsed to about 1 percent of GDP during the Long Depression that followed the Panic of 1873-which itself was the result of over expansion during American post-Civil War boom. A fresh cycle began in the 1880s with Britain's capital exports increasing to more than 7 percent of GDP - only to collapse again to less than 2 percent of GDP after the Panic of 1893, when half the American railway companies went bankrupt; Argentina defaulted; many other Latin American countries (including Brazil) also either defaulted or ran into debtservicing difficulties; and Portugal and Greece unilaterally reduced their interest payments.

By the turn of the century, however, British lending had resumed as Argentina and Brazil restored their creditworthiness, American railways emerged from bankruptcy, and the establishment of the national gold standard boosted confidence in US investments. British political alliance with Japan in 1902, and with Russia in 1907, increased sovereign lending to these countries, while the 1900 Colonial Stocks Act - which made lending to colonial governments eligible for inclusion in trust portfolios - encouraged lending to the empire and dominions. By the eve of World War I in 1914, British national saving had reached 16 percent of GDP, of which more than half was being invested abroad, while the stock of British foreign assets amounted to (the equivalent of) US\$18.5 billion, more than one and one-half times national income (or one-quarter of national wealth).

\footnotetext{
${ }^{10}$ Hobson (1914) discusses how, in the eighteenth century, London gained supremacy over Amsterdam as an international financial center (Britain was probably a net debtor until after the end of Napoleonic Wars, but British financiers participated in foreign loans long before then), and the debate about whether Britain was exporting too much capital at that time given its own industrialization and development needs. Viner (1928) notes that in the fifteenth and sixteenth century French literature, the term Anglais had already been used as a derogatory term signifying 'creditor.' Hobson (1914), Feis (1965), and Simon (1968) discuss the geographical pattern of British lending in the late eighteenth century and early nineteenth century.
} 
Figure 1. Net Capital Flows, 1860-1913 (in percent of GDP)
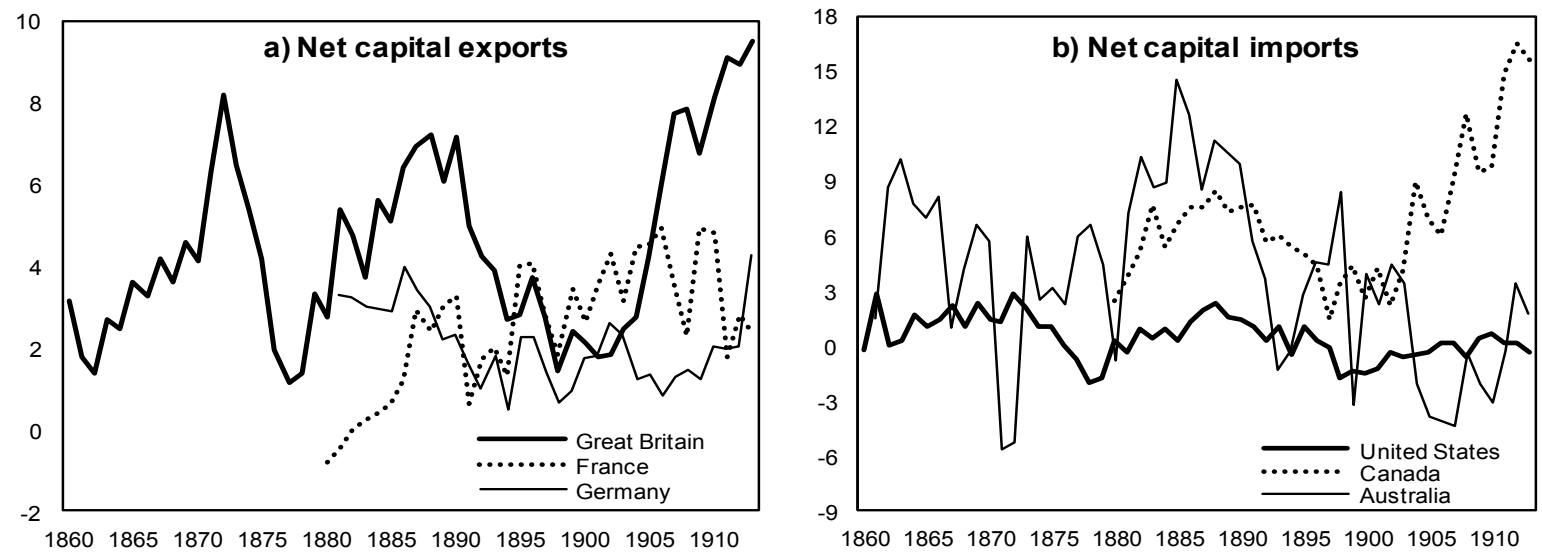

Sources: Authors' estimates based on Bloomfield (1968), and International Historical Statistics.

Underpinning these massive cross-border flows was both the gold standard - which provided long-term exchange rate stability and eliminated currency risk - and the absence of capital controls or other legal impediments to capital flows. ${ }^{11}$ Britain was the most liberal in this regard. Despite the large volume of outflows, foreign investment faced little opposition from industry because it was often associated with increased orders for British exports of railway lines, rolling stock, and other capital equipment. ${ }^{12}$ This liberal attitude was reflected in the laissez-faire official policy, which seldom restricted foreign issuances in the domestic market, except in a few instances where the political aims of the borrowing government ran contrary to British interests. ${ }^{13}$

France and Germany, the other major capital exporters (with end-1913 stocks of foreign assets amounting to US\$8.8 billion and US\$5.5 billion, respectively), presented somewhat different situations. France's pattern of industrialization, with its greater emphasis on fine, artisanal products rather than mass produced manufactures, meant that there were fewer domestic calls for savings (other than for railways and for French government bonds, rentes), which freed up funds for foreign investment. Nevertheless, by restricting listings on the Paris Bourse, French officials kept tight reins on the destination of foreign investments - directing

\footnotetext{
${ }^{11}$ The primary objective of central banks at that time was to maintain external stability. Cast in terms of the "trilemma," monetary policy was subordinated to the goals of exchange rate stability and capital mobility.

${ }^{12}$ Of the stock of British foreign investment, 40 percent was in the securities of railway companies, 12 percent in capital-intensive industries, and 30 percent consisted of loans to national or state governments (around onehalf of which were associated with public infrastructure investments; Feis, 1965; p. 27). Figures provided by Hobson (1914) suggest that between 1900-09, British exports accounted for around one-half of rails, locomotives, and rolling stock imports by India and Argentina; and around one-quarter to one-third of imports by Australia and South Africa.

${ }^{13}$ There was some "self-censorship" whereby respectable private banks that habitually handled sovereign issuances would not promote, and the public would not buy, the securities of foreign governments whose aims ran contrary to British interests. Overt intervention by the Foreign Office was therefore usually unnecessary (Feis, 1965; p. 91). Viner (1928) discusses some of the restrictions on capital exports exercised by the authorities in the capital exporting countries of that time.
} 
them toward political or business advantage. ${ }^{14}$ In Germany, where the development of heavy industry and the needs of the state absorbed a substantial portion of domestic saving, the basic impetus for foreign investment was weaker, and the determination to ensure that German business or the state benefit directly from the nation's foreign investments was correspondingly greater. Again, without imposing capital controls or exchange restrictions, but by limiting listings on the German stock exchange, and by determining the securities eligible for use as collateral for re-discounting at the central bank (Reichsbank), the state could exercise significant influence over lending for foreign companies or countries. ${ }^{15}$

On the recipient country side also, there were relatively few restrictions targeting inflows, and those that did exist were mainly directed at limiting foreign control of important corporations and sectors of the economy (what, in interwar Germany, came to be termed ueberfremdung _ “alienation of control"). More broadly, inflow restrictions at that time aimed at preventing political influence or subjugation by capital exporting countries. Thus, a Russian decree of 1887 prohibited the ownership of land by foreigners along Russian frontier with Asia and Poland; and a Prussian law of 1909 intending to limit French control over German coalfields, made acquisition of mining properties subject to state approval. ${ }^{16}$ Likewise, in 1910 Sweden required that the principal officers of certain large corporations be Swedish citizens, while Czechoslovakia adopted restrictions on capital imports for fear of complications with foreign governments over their citizens' investments.

In less economically developed parts of the world, there were usually fewer indigenous corporations for ueberfremdung to be a concern. Nevertheless, foreign investment at times met stiff local resistance (occasionally prompting national governments to rescind permits), not always because they were foreign investment, but because in the course of industrialization, capital — which happened to be mainly foreign — came into conflict with labor, or threatened traditional ways of life and existing socio-economic structures (though the fact of foreign ownership often provided a convenient rallying cry for its opponents. $)^{17}$

In sum, during this golden era of financial globalization, capital flows from the leading economies of the day helped finance the needs of industry and the state in the less developed parts of the world - the "emerging markets" of the era - though they likely contributed to

\footnotetext{
${ }^{14}$ For instance, the 1910 Report of the Board of Directors of the Comptoire National d'Escompte, notes: "In the selection of securities we offer to our clientele, we undertake, as a rule, not only to seek security of investment but also to take into account the view of our government and the economic and political advantages that may be obtained by France by the loans contracted by other countries" (Feis, 1965, p. 123).

${ }^{15}$ The promotion of German business interests was facilitated by the close connection between banks and industry, as evident from the testimony of a director of Friedrich Krupp AG (the largest company in Europe in the early 20th century) to the German Bank Inquiry of 1908-09: "I believe that the existing state of things suffices to enable the government to hold up undesirable loans or prevent them being placed at an inopportune moment" (Feis, 1965, p. 168).

${ }^{16}$ Even earlier, in 1824, Pennsylvania banned the transfer of bank stock to non-US citizens and, in 1825 , prohibited foreigners (except Dutch citizens) from holding the stock of the Bank of North America unless investor declared his intention of becoming a naturalized American (Staley, 1935).

${ }^{17}$ See Staley (1935), chapter 14, for a discussion.
} 
periodic boom-bust cycles and financial panics as well. Capital flows were largely long term in nature. ${ }^{18}$ There were few restrictions on either capital inflows or outflows - though officialdom in each of the major capital exporters exercised varying degrees of influence over lending to foreign sovereigns, mostly for political reasons.

Table 1. Long-term Publicly Issued Capital Investment Stock, 1914 (in mln.)

\begin{tabular}{|c|c|c|c|c|c|c|}
\hline & \multicolumn{2}{|c|}{ Britain } & \multicolumn{2}{|c|}{ France } & \multicolumn{2}{|c|}{ Germany } \\
\hline & $\begin{array}{c}\text { US } \\
\text { dollars }\end{array}$ & $\begin{array}{c}\text { In percent } \\
\text { of total }\end{array}$ & $\begin{array}{c}\text { US } \\
\text { dollars }\end{array}$ & $\begin{array}{c}\text { In percent } \\
\text { of total }\end{array}$ & $\begin{array}{c}\text { US } \\
\text { dollars }\end{array}$ & $\begin{array}{c}\text { In percent } \\
\text { of total }\end{array}$ \\
\hline Europe & 535 & 2.9 & 2,538 & 28.7 & 2,104 & 37.9 \\
\hline Austria & 39 & 0.2 & 433 & 4.9 & 709 & 12.8 \\
\hline Balkan States & 84 & 0.5 & 492 & 5.6 & 402 & 7.2 \\
\hline Italy & 62 & 0.3 & 256 & 2.9 & & \\
\hline Portugal and Spain & 134 & 0.7 & 767 & 8.7 & 402 & 7.2 \\
\hline Other Europe & 217 & 1.2 & 590 & 6.7 & 591 & 10.6 \\
\hline Australia and New Zealand & 2,053 & 11.1 & & & & \\
\hline North America & 6,258 & 33.7 & 394 & 4.4 & 875 & 15.7 \\
\hline Canada & 2,538 & 13.7 & & & & \\
\hline United States & 3,720 & 20.1 & & & & \\
\hline South America & 3,730 & 20.1 & 1,181 & 13.3 & 898 & 16.2 \\
\hline Argentina & 1,576 & 8.5 & & & & \\
\hline Brazil & 730 & 3.9 & & & & \\
\hline Mexico & 488 & 2.6 & & & & \\
\hline Other Americas & 937 & 5.0 & & & & \\
\hline Asia & 2,572 & 13.9 & 433 & 4.9 & 236 & 4.3 \\
\hline India and Ceylon & 1,867 & 10.1 & & & & \\
\hline China & 216 & 1.2 & & & & \\
\hline Japan & 310 & 1.7 & & & & \\
\hline Other Asia & 178 & 1.0 & & & & \\
\hline Africa & 2,009 & 10.8 & & & 473 & 8.5 \\
\hline South Africa & 1,825 & 9.8 & & & & \\
\hline Other Africa & 184 & 1.0 & & & & \\
\hline Egypt & 221 & 1.2 & 649 & 7.3 & & \\
\hline Turkey & 118 & 0.6 & 649 & 7.3 & 426 & 7.7 \\
\hline Russia & 542 & 2.9 & 2,223 & 25.1 & 426 & 7.7 \\
\hline Other & 513 & 2.8 & 787 & 8.9 & 118 & 2.1 \\
\hline Total & 18,552 & 100.0 & 8,854 & 100.0 & 5,555 & 100.0 \\
\hline Total (percent of GDP) & & 160 & & 90.8 & & 44.8 \\
\hline
\end{tabular}

\footnotetext{
${ }^{18}$ Short-term capital flows in that period reflected seasonal balance of payments needs, or "stabilizing speculation." (As noted by Eichengreen (1992), gold standard was a highly credible target zone-with upper and lower bands determined by the gold import and export points. Such a regime will be characterized by "stabilizing" speculative flows because as the exchange rate approaches the lower band, it can only appreciate and thus attract capital flows, which indeed help strengthen the currency.)
} 


\section{B. The Interwar Period}

During World War I, private capital largely ceased to flow across national boundaries (especially from Europe, which had been the main source of global capital), and the gold standard de facto stopped operating. The cessation of hostilities revealed deep differences in attitude toward restoring cross-border capital flows. At one extreme was the Soviet Union, which under an authoritarian and state socialist model had imposed tight controls on capital movements by 1919; and at the other extreme were the private and central bankers of the leading economies of the day (including the United States, that had gone from being the world's largest debtor to the largest creditor), seeking to re-establish the previous liberaland for the great banking houses, highly profitable - international monetary order. The 1922 Genoa Economic and Monetary Conference, held to discuss and resolve problems in the post-war economic and financial reconstruction of Europe (and build ties with the Soviet Union), thus resolved that, "all artificial control of exchange ... is futile and mischievous and should be abolished at the earliest possible date." 19

Wartime dislocation, currency misalignments, and deficit financing of reparations and reconstruction costs delayed this process, especially in Europe. ${ }^{20}$ But starting with the 1924 Dawes Plan and associated Dawes Loan (publicly-endorsed but privately funded), Germany managed to stabilize its economy and put its new currency, the Reichsmark, on the gold standard. Britain returned to gold in 1925 at her pre-war parity. France also de facto returned to gold in 1926 (de jure in 1928), albeit at a much depreciated exchange rate. By the late 1920 s, most of the world's major economies were back on the gold standard (Figure 2). ${ }^{21}$

Buoyed by the success of the Dawes Loan, and underpinned by the re-established gold standard, American banks entered a period of massive private international lending, averaging about a billion dollars a year over 1924-29, half of which was destined for Europe, partly intermediated by British banks (Figure 3). Town halls in Germany were said to be inundated by representatives of international banks offering aggressively priced credits, spurring a huge economic and financial boom. ${ }^{22}$

\footnotetext{
${ }^{19}$ Resolution 14 of the Financial Commission of the Genoa Economic and Monetary Conference; see Mills (1922; p. 366). In order to conserve on scarce monetary gold, the Conference also recommended that most central banks be on a gold exchange standard (i.e., back their currencies with gold and foreign exchange), while only the major reserve currencies adopt a gold-coin/gold-bullion standard (i.e., payable in gold upon demand).

${ }^{20}$ The 1921 London Conference put Germany's responsibility for the war at 132 billion Gold Marks (the equivalent of US\$ 32 billion, or more than 1.5 times Britain's pre-war stock of net foreign assets). The actual schedule of reparations was 50 billion Gold Marks, or US\$12 billion. During 1920-24, world output grew at 16 percent, whereas European output grew at only 2 percent (League of Nations, 1932).

${ }^{21}$ The United States maintained the gold standard almost throughout World War I, suspending convertibility only twice - once in July 1914 at the onset of the War, and then in 1917 as it entered the War (Crabbe, 1989).

${ }^{22}$ See Brown (1987) and Eichengreen (1992) for a detailed account of that period. Over 1925-29, European output grew at 31 percent (compared to 20 percent of world output growth); while the demand for US machine tools rose by 87 percent (League of Nations, 1932).
} 
Figure 2. Rise and Fall of the Interwar Gold Standard

(Total number of major countries on gold/gold exchange standard)

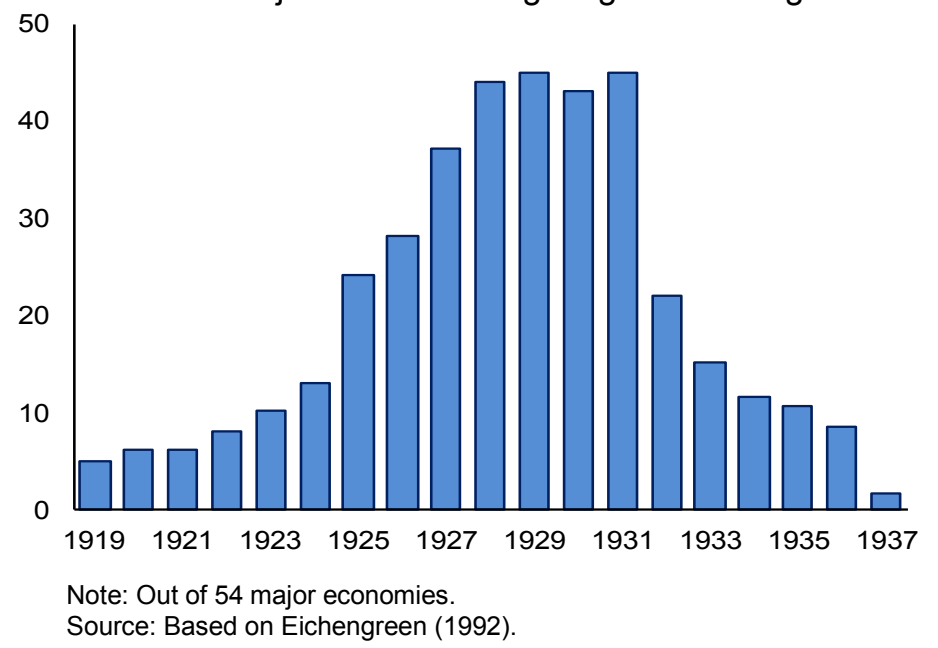

Figure 3. Net Capital Flows to Selected Countries, 1923-44 (in USD mln.)

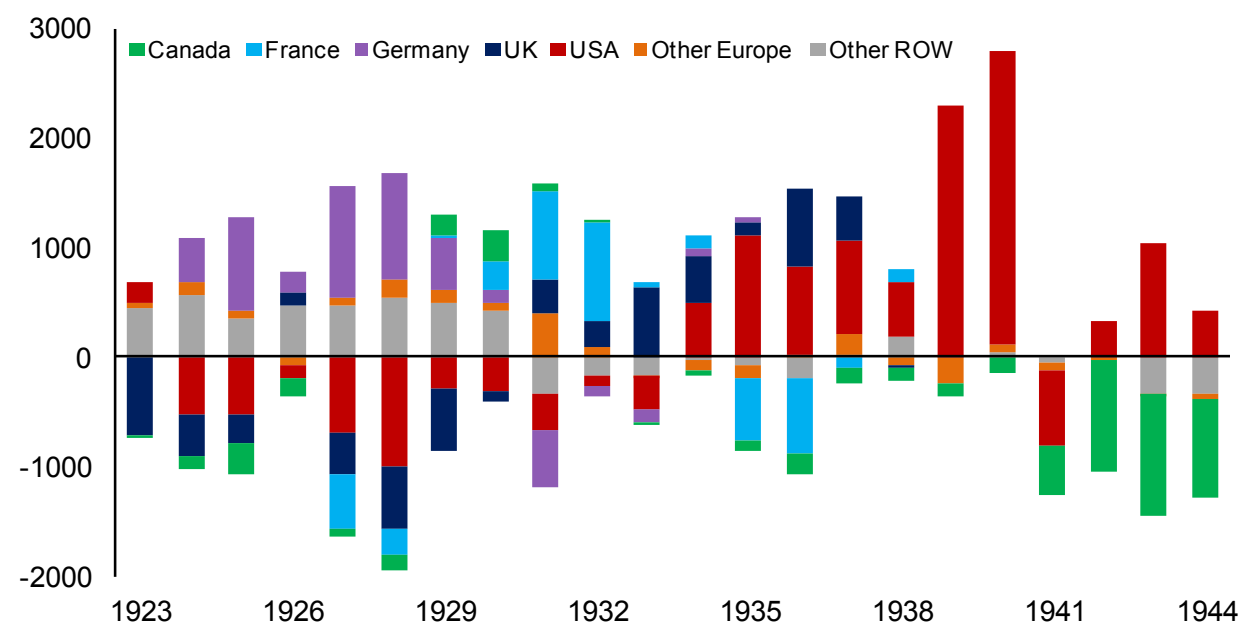

Source: League of Nations (1931,1932, 1939, 1948).

Note: Net capital flows include errors and omissions. Countries are included based on data availability, as follows: Canada (1923-44); France (1927-38); Germany (1924-35); UK (1923-38); USA (1923-44); Other Europe: Czecho-Slovakia (1925-37), Denmark (1923-39), Estonia (1924-38), Greece (1929-38), Hungary (1923-37), Latvia (1923-37), Netherlands (1929-39), Norway (1923-44), and Sweden (192344); Other ROW: Argentina (1923-44), Australia (1923-37), Dutch Indies (1925-39), India (1924-38), Japan (1924-36), New Zealand (1927-37), South Africa (1923-37), and Turkey (1926-33).

But this resurrection of the liberal international order did not last long. The lending boom of the Dawes and other credits to Europe had not solved the underlying adjustment problemwhereby creditor nations were unwilling to increase imports to allow debtor countries to service their debts - it had merely postponed it. When a boom in the New York stock market (which ultimately ended spectacularly in the October 1929 crash) drew both domestic and foreign capital to the United States, Europe suffered an equally massive sudden stop (Figure 3). By September 1930, Germany was experiencing funding difficulties and the Reichsbank suffered a run, losing RM1 billion (US\$250 million) in the last quarter of the year, with 10 
percent of foreign exchange reserves lost in a single day. ${ }^{23} \mathrm{~A}$ six month loan (with up to three renewals) of US\$125 million temporarily stabilized the situation, but in May 1931, the Creditanstalt, a major Austrian bank, disclosed heavy losses, triggering a global financial crisis as the debt unsustainability of Austria, Germany, and Eastern European countries became evident. With Germany unable to meet her short-term obligations to banks, the government declared a standstill on foreign payments and imposed exchange restrictions in July 1931. This triggered a run on Pound sterling as British banks were known to be heavily exposed to Germany and Eastern Europe-forcing Britain off the gold standard in September 1931 , with most of her dominions and numerous other countries following suit. ${ }^{24}$

What ensued was a decade of almost dizzying capital flight, hot money flows, competitive devaluations, exchange restrictions and capital controls (nearly all on outflows), protectionism, and imploding global trade. ${ }^{25}$ The immediate impact of Pound sterling's devaluation was a drain of capital from the United States as investors, including central banks, lost confidence in the gold exchange standard and started hoarding gold instead of reserve currencies; in April 1933, the US devalued the dollar. In turn, the dollar devaluation put speculative pressure on the Dutch Florin and the Swiss Franc_-both of which were still pegged to gold at their pre-war parities - as well as on the French Franc, the largest economy still on gold, and on the other gold bloc countries (Belgium, Italy, and Portugal). In sequence, countries abandoned the gold standard and devalued, imposed exchange restrictions (of varying severity on the availability of foreign exchange for capital and current account transactions), or did a combination of the two (Figure 4).

Figure 4. Exchange Restrictions and Abandoning of Gold Standard, July 1931-July 1932

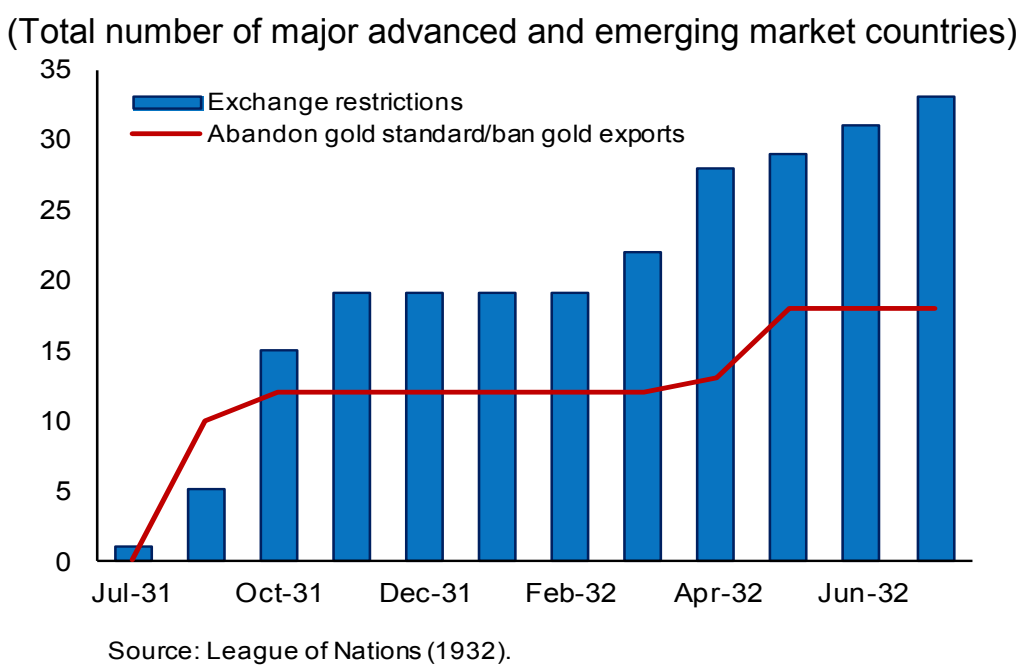

\footnotetext{
${ }^{23}$ Source: League of Nations (1932; p. 72-74).

${ }^{24}$ The Bank of England's gold reserves fell from $£ 163.2$ million on July 1, 1931 to 1133.6 million on September 23, 1931 (and further to £120.0 million by November 4, 1931). See Fanno (1939; p. 65) for a detailed discussion of "normal" and "abnormal" capital movements during the interwar period.

${ }^{25}$ See, for example, League of Nations $(1938,1944)$ for details.
} 
Following the dollar devaluation, as the US economic recovery gained momentum, and against a background of worrying political developments in Europe, capital flows to the US resumed. In 1935, US capital inflows - comprising mostly short-term funds - reached US\$1.5 billion, and increased further to more than US\$2 billion in 1939 (Figure 5). These large inflows, especially during 1935-37, concerned the US administration for several reasons. Foreign funds were believed to be contributing to an unhealthy speculative boom in the stock market. Inflows were also swelling the US banking system's excess reserves, which could precipitate an inflationary spiral and credit boom outside of the normal channels of control of the Federal Reserve. Equally worrying, there was a risk that foreign countries' loss of gold reserves through capital flight might prompt them to impose trade restrictions on US exports, undermining the nascent recovery. Finally, there was the possibility that foreigners might become large sellers in the event of war or other developments in Europe. Marriner Eccles, the then Chairman of the Federal Reserve, noted in 1937:

Since such inflows complicate the problem of achieving and maintaining a prosperous stability, constitute a source of embarrassment to many countries from which the capital is flowing, and .... have nothing to do with foreign trade or the international division of labor, there appears to be a clear case for adopting measures designed to deter the growth of foreign capital holdings in our markets. ${ }^{26}$

Yet the US did not impose controls on capital inflows. ${ }^{27}$ Beyond certain practical difficulties in taxing foreigners, there was almost no precedent for inflow controls (the exception being Switzerland, which in 1937 abolished interest payments on nonresident deposits; levied a one percent commission; and required advanced notice for withdrawals of such deposits). ${ }^{28}$ Drawing on the experience of countries trying to control capital flight, there was also the belief that to be effective, the restrictions would need to be broad-based, covering both capital and current transactions. Perhaps more importantly, there was a general distrust of any such measures owing to the capital outflow restrictions imposed by undemocratic, dictatorial regimes (such as Austria, Germany, and the Soviet Union) in the interwar period. As Bloomfield (1950) notes:

Exchange control over capital movements and current account transactions alike was generally regarded in these circles as inherently objectionable and a perversion of the pattern of international payments worthy only of totalitarian countries or justifiable only under conditions of extreme necessity.

\footnotetext{
${ }^{26}$ Source: Fortune, April 1937 (https://fraser.stlouisfed.org/docs/historical/eccles/068_05_0005.pdf).

${ }^{27}$ The Federal Reserve, however, doubled reserve requirements of member banks in 1936-37 to counteract the inflationary pressure of the large gold inflows.

${ }^{28}$ Argentina and Sweden also reduced interest payments on nonresident deposits (Bloomfield, 1950; p. 194).
} 
Henry Morgenthau, the US Secretary of Treasury, summed up the prevailing attitude when he wrote in 1937, "I am opposed to exchange control, except as a last resort. Frankly, I disapprove of exchange control." ${ }^{29}$

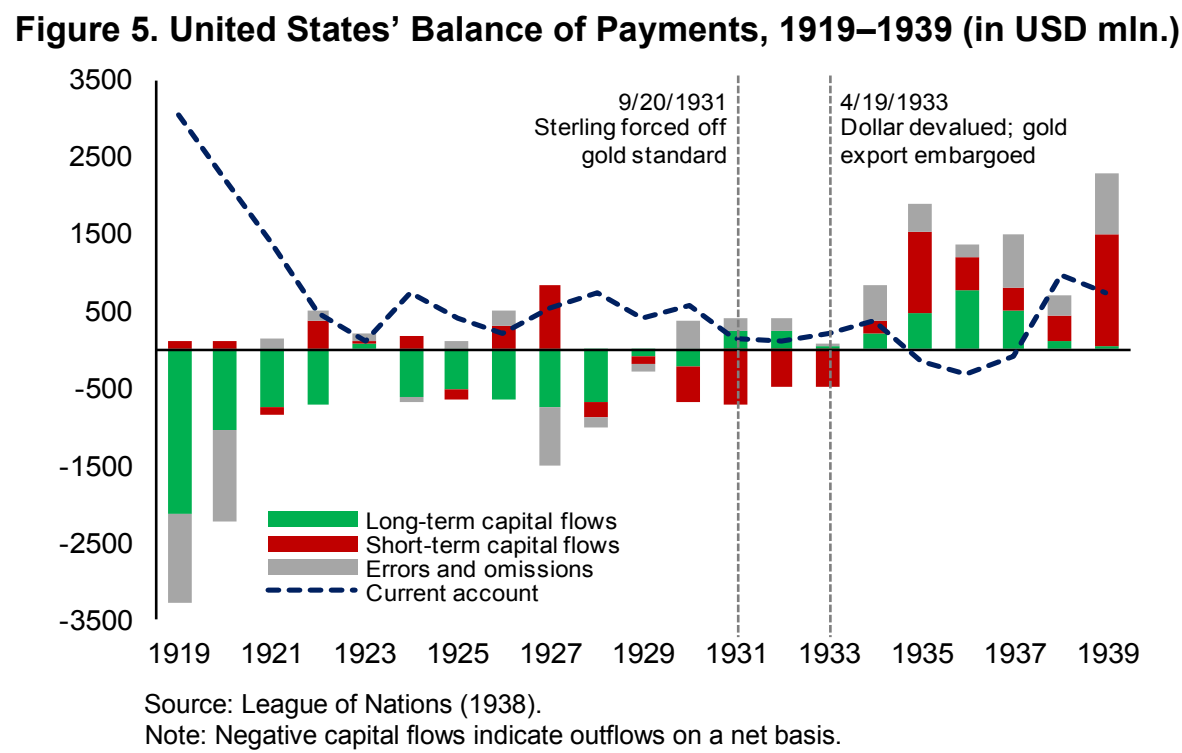

\section{The Bretton Woods Era}

Beyond its intrinsic interest, the interwar period is important because of the way it shaped thinking at the Bretton Woods Conference in July 1944, where delegates of 44 nations gathered to design a new international monetary system that would bring order to the interwar economic chaos. The lesson that the main protagonists at the conference-John Maynard Keynes and Harry Dexter White - took from the interwar experience was that a regime of unfettered capital flows is fundamentally inconsistent with the macroeconomic management increasingly expected of governments (namely, to strive for full employment), or with a liberal international trade regime. ${ }^{30}$ Given the choice, they preferred free trade to free capital flows - especially to short-term "hot money" flows and flight capital. Hence the emphasis in the IMF's Articles of Agreement (drawn up at the Bretton Woods Conference) on current, rather than capital account convertibility, and the explicit recognition that countries may need to impose capital controls.

Keynes and White thus envisaged capital controls as a structural element of the international financial landscape, rather than as just temporary or transitional measures. They also realized that capital controls would not be effective unless applied "at both ends" of the transaction, and their original plans therefore mandated IMF member countries to cooperate in enforcing

\footnotetext{
${ }^{29}$ New York Times, February 16, 1937, p. 31; cited in Bloomfield (1950; p. 183).

${ }^{30}$ Boughton (2002) argues that White and Keynes developed their views about capital controls independently of each other; whereas for White, in his early thinking, controls were second best ("the best of the bad choices"), for Keynes, they were second nature.
} 
each other's measures (partly in lieu of more Draconian exchange restrictions that they thought would be necessary to make unilateral controls effective; Helleiner, 2015). ${ }^{31}$ Last minute intervention by powerful New York bankers, however, succeeded in watering down these proposals, and in the final version of the IMF Articles agreed at Bretton Woods on $22^{\text {nd }}$ July 1944, capital controls were not included as a permanent feature of the international financial landscape (Helleiner, 1994). Instead, Article VI.3 merely noted that "members may exercise such controls as are necessary to regulate international capital movements." ${ }^{32}$ The requirement that member countries cooperate in enforcing each other's capital control measures was also not part of the final Articles; according to Article VIII.2(b), countries "may, by mutual accord, cooperate in measures for the purpose of making the exchange control regulations...more effective." 33

Despite this early push back by US banking interests, the Bretton Woods era was characterized by widespread use of restrictive measures (Figure 6). As in the interwar period, these were mainly controls on outflows rather than on inflows; unlike that period, they were typically not exchange restrictions but specifically capital controls since the IMF's Articles prohibit exchange restrictions on current account transactions (except transitionally or with the IMF's approval). The measures were also unilateral since the United States, which was the major recipient of capital flight, declined to cooperate in enforcing other countries' outflow restrictions. Helleiner (1994) argues that this refusal to cooperate (which would have required furnishing foreign governments with information on their nationals' holdings of assets in the US) reflected the further re-assertion of US banking interests, facilitated by changing attitudes within the US Treasury - which became more orthodox, as Secretary Morgenthau was replaced by Fred Vinson, and shortly later by John Snyder who had formerly been an investment banker. In fact, in his testimony to US Congress in 1948,

\footnotetext{
${ }^{31}$ The idea that cooperative controls might be much more effective was not unique to Keynes and White. Ragnar Nurske wrote in his 1944 report International Currency Experience: Lessons of the Inter-War Period: "In considering the question whether it is possible to have a system of exchange control affecting capital movements alone - and particularly, of course, capital movements of the speculative of "disequilibrating" kind - we should remember that the inter-war period affords no experience of a generalized exchange control as exists today (1944). Control was applied unilaterally by such individual countries as happened to be subject to a threat of capital flight. If control were exercised by capital-receiving as well as by capital-losing countries, the answer might be different" (League of Nations, 1944; p. 164). Recent empirical evidence suggests that "operating at both ends" of cross-border capital movements is indeed more effective than trying to control movements with inflow- or outflow-controls alone (see Ghosh et al., 2014).

${ }^{32}$ The potential inconsistency between the freedom of IMF members to exercise controls under Article VI.3, and the prohibition under Article VIII.3 against discriminatory currency arrangements, was discussed by the IMF Executive Board on April 6, 1956. The Board concluded that "Article VI.3 recognized the sovereign right of members to regulate international capital movements in any way that would not restrict current payments, including permitting discriminatory currency arrangements insofar as they were for the purpose of controlling capital movements" (Horsefield, 1969; p. 404).

${ }^{33}$ Moreover, the IMF could not require a member country to impose controls on outflows when IMF resources were financing capital flight, it could only "request" that the country restrict outflows (and make it ineligible for further use of IMF resources if it failed to do so). Curiously, that the Articles do not explicitly address the use of inflow controls implies that as part of its program conditionality, the IMF can require a country to impose controls on capital inflows under the general provisions of Article V.3(a) - see Capital Movements: Legal Aspects of Fund Jurisdiction Under the Articles (IMF SM/97/32, Supplement 3, February 21, 1997).
} 
Snyder stated that controlling capital inflows would require exchange controls that "would do maximum violence to our position as a world financial center and to our policy of keeping the dollar substantially free of restrictions." ${ }^{34}$

Figure 6. Capital Controls in Advanced and Emerging Market Economies, 1950-2010

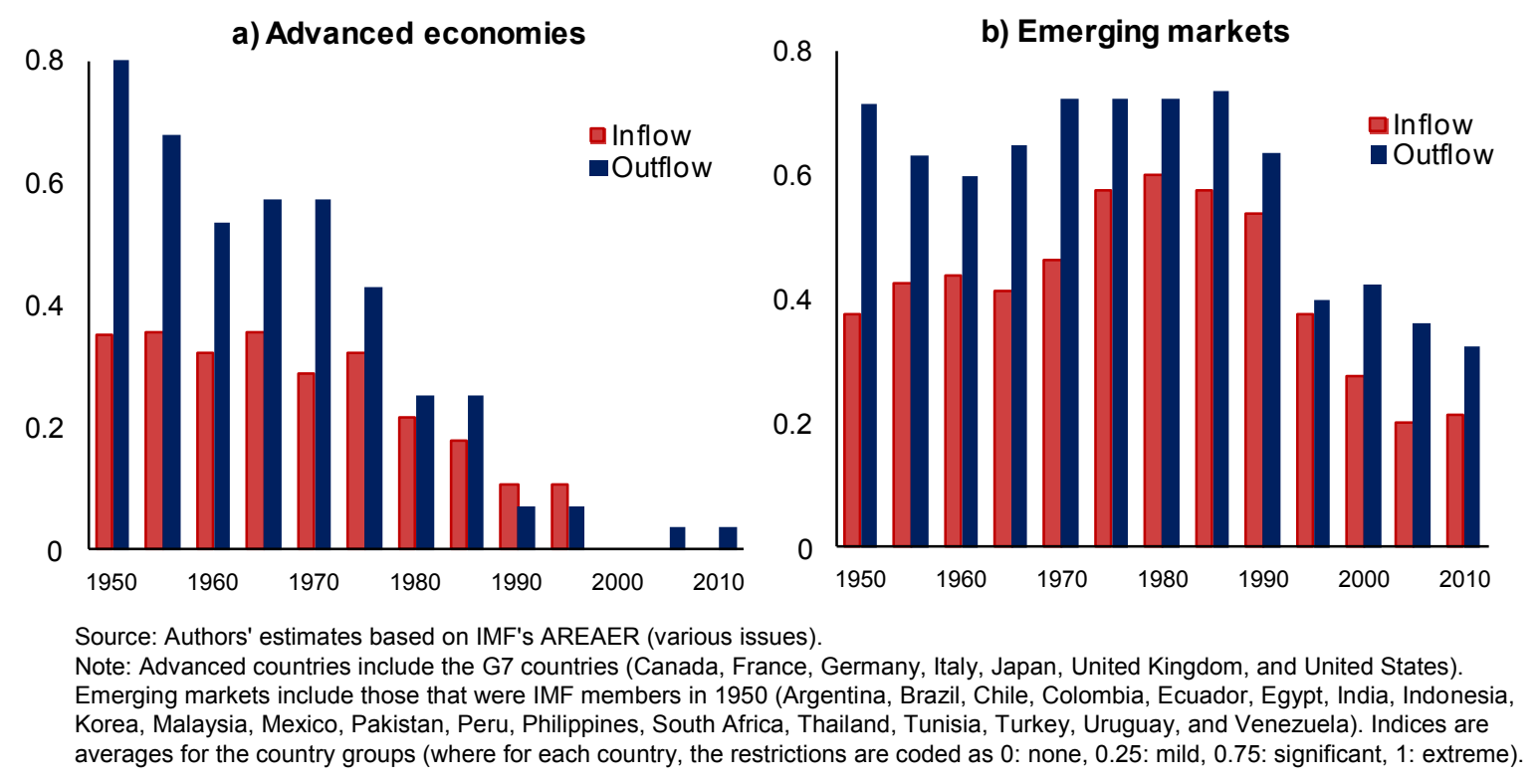

A prominent example of capital controls in that period is that of Britain. Following a disastrous "dash to convertibility" in 1947, which ended within six weeks with a run on the Pound sterling, Britain imposed strict controls on capital outflows that were maintained until 1979 (current account convertibility under IMF Article VIII was achieved in 1961). It is worth noting, however, that despite US resistance to control capital inflows, the US Federal Reserve and the Treasury agreed (for strategic reasons) in 1949 to help the Bank of England defend the pound by cracking down on sterling transactions in the New York foreign exchange markets, which were illegal under British exchange controls (Helleiner, 1994). In 1949, the IMF also released a statement repeating the obligations of member countries (under Article VIII.2(b)) to make "unenforceable" the foreign exchange dealings in their territories that violated other members' exchange controls. ${ }^{35}$

\footnotetext{
${ }^{34}$ Cited in Helleiner (1994, p. 60).

${ }^{35}$ As the Legal Department explained to the Executive Board on October 29, 1948, the "unenforceability of exchange contracts under Article VIII.2(b), means that the courts in members' territories must not lend their assistance to implement the obligations of such contracts"-in other words, it was not that such contracts would be illegal per se, but that if one of the parties to the transaction failed to fulfill his obligations under the contract, the other party would not have recourse to the courts to enforce the contract (see Horsefield, 1969, p. 209-210; Gold, 1962; p. 60-68). In addition, the legal opinion clarified that Article VIII.2(b) applied to all members, including those availing themselves of the transitional Article XIV, and not just those that had assumed the obligations of Article VIII.
} 
Despite the outflow controls, the 1950s and 1960s saw the birth and boom of the Eurodollar market in London. Schenk (1998) argues that this was partly the result of a "loophole" in the regulations, which permitted transactions on the forward exchange market. While aware of this loophole, and concerned about the implications of the rise of Eurodollar deposits, the Bank of England and Treasury tolerated the trend to keep London as an international financial center. ${ }^{36}$ A Bank of England report of 1963, thus, notes:

$[\mathrm{H}]$ owever much we dislike hot money we cannot be international bankers and refuse to accept money. We cannot have an international currency and deny its use internationally. ${ }^{37}$

Elsewhere in Europe (and Japan), likewise, current account convertibility was achieved by the late 1950s or early 1960s, but with the exception of Germany, full capital account liberalization had to await the 1980s. Indeed, during the initial post-war decades, advanced economies (with the exception of Canada, Germany, Switzerland, and the US) were generally more restrictive in regard to capital flows than many developing and emerging market economies (Figure 6). Even Germany-which achieved currency convertibility in 1958 - occasionally imposed inflow controls in late 1950s and 1960s to deal with speculative capital movements (Table 2). For instance, in 1957, it imposed higher reserve requirements on nonresident bank deposits to prevent credit being extended against these deposits, which largely represented short-term speculative capital flows in anticipation of Pound sterling devaluation (Goode and Thorn, 1959). An authorization requirement was also imposed in June 1960 on the purchase of domestic money paper by nonresidents, along with a ban on interest payments on nonresident bank deposits.

Nevertheless, the trend during the 1950s and 1960s in advanced economies was toward capital account liberalization. Part of the impetus for capital account liberalization came from the recognition that rising trade integration and internationalization of commercial activitiy (for instance, by multinational corporations) made it increasingly difficult to restrict capital transactions without also having an impact on current transactions (Goodman and Pauly, 1993). This impetus was enshrined in the 1961 OECD Code of Liberalization of Capital Movements, though it is noteworthy that the Code initially explicitly excluded short-term capital flows from liberalization obligations. The Code was occasionally interrupted as individual countries suffered balance of payments difficulties. As early as 1963, for example, concerned by capital outflows that were causing persistent balance of payments deficits and undermining confidence in the dollar, the US imposed an Interest Equalization Tax on foreign issuances in its markets. By 1970, as the US current account turned to deficit, this measure was broadened to incorporate both voluntary and mandatory foreign credit

\footnotetext{
${ }^{36}$ Although both the Bank of England and the Treasury shared the view that London should remain an important financial center, Schenk (1998) notes that "the Treasury was more cautious than the Bank, sometimes complaining that the latter was under excessive influence by financial institutions."

${ }^{37}$ Report by JML for Hamilton, 19 October 1961. BE EID 10/19; cited in Schenk (1998).
} 
restraints, including an outright embargo on net direct investment outflows to continental Europe. Helleiner (1994) notes that the measures reflected skepticism among US policy makers concerning the benefits of a liberal financial order:

The 1967 Economic Report of the President, for example, justified capital controls on the grounds that financial flows were not producing an optimum distribution of the world's scarce capital but rather were responses to differences in national monetary policies, taxation, financial structures, and cyclical economic trends. Even the American Bankers Association was forced to admit in 1968 that the case for free capital movements was weak, given that many such movements were speculative, unproductive, and tax-avoiding.

At the other end, countries such as Australia, Germany, Japan, and Switzerland, that were the recipients of increasingly large flows speculating on the possibility that the dollar would be devalued, imposed restrictions on short-term inflows (Table 2). Australia, for example, put an embargo on short-term borrowing, and imposed deposit requirements on other borrowing. Japan tightened controls on portfolio inflows, and imposed marginal reserve requirements on nonresident deposits. Germany imposed a cash deposit requirement (Bardepot) on foreign loans, suspended interest payments on nonresident deposits, and imposed marginal reserve requirements on the growth of banks' external liabilities. Switzerland launched a "gentleman's agreement" with domestic banks not to accept short-term foreign currency deposits (Schenk, 1998). Swiss banks also agreed not to pay interest on foreign deposits, or to invest foreign capital in domestic securities and properties, as well as to charge a fee on deposits withdrawn within six months.

Despite these increasingly desperate measures, the dollar was devalued in August 1971, and the major currencies were realigned at the Smithsonian Agreement in December that year. The effective devaluation of the dollar of around 10 percent, however, was not sufficient to restore equilibrium in the US balance of payments, which came under renewed stress in 1972 and early 1973 (Figure 7). Surprisingly, at that stage, the US not only declined to strengthen its outflow controls, but it actively opposed international cooperation in the administration of inflow and outflow controls that was being advocated by both the Japanese and the Europeans. Helleiner (1994) attributes this shift in the attitude to the realization by US officials that unfettered private capital flows would be able to achieve in short order what they had failed to do in years of international negotiation: force currency appreciation in Japan and the European surplus countries, thus facilitating US external adjustment. ${ }^{38}$

\footnotetext{
${ }^{38}$ Paul Volcker recounts the difficulties in persuading US' trading partners to accept revaluations of their currencies at Smithsonian (Volcker and Gyohten, 1992; p. 80-90). See Solomon (1982) for a discussion on earlier US efforts to engineer a revaluation of trading partners' currencies.
} 
Table 2. Selected Cases of Inflow Controls Tightening in Advanced Economies

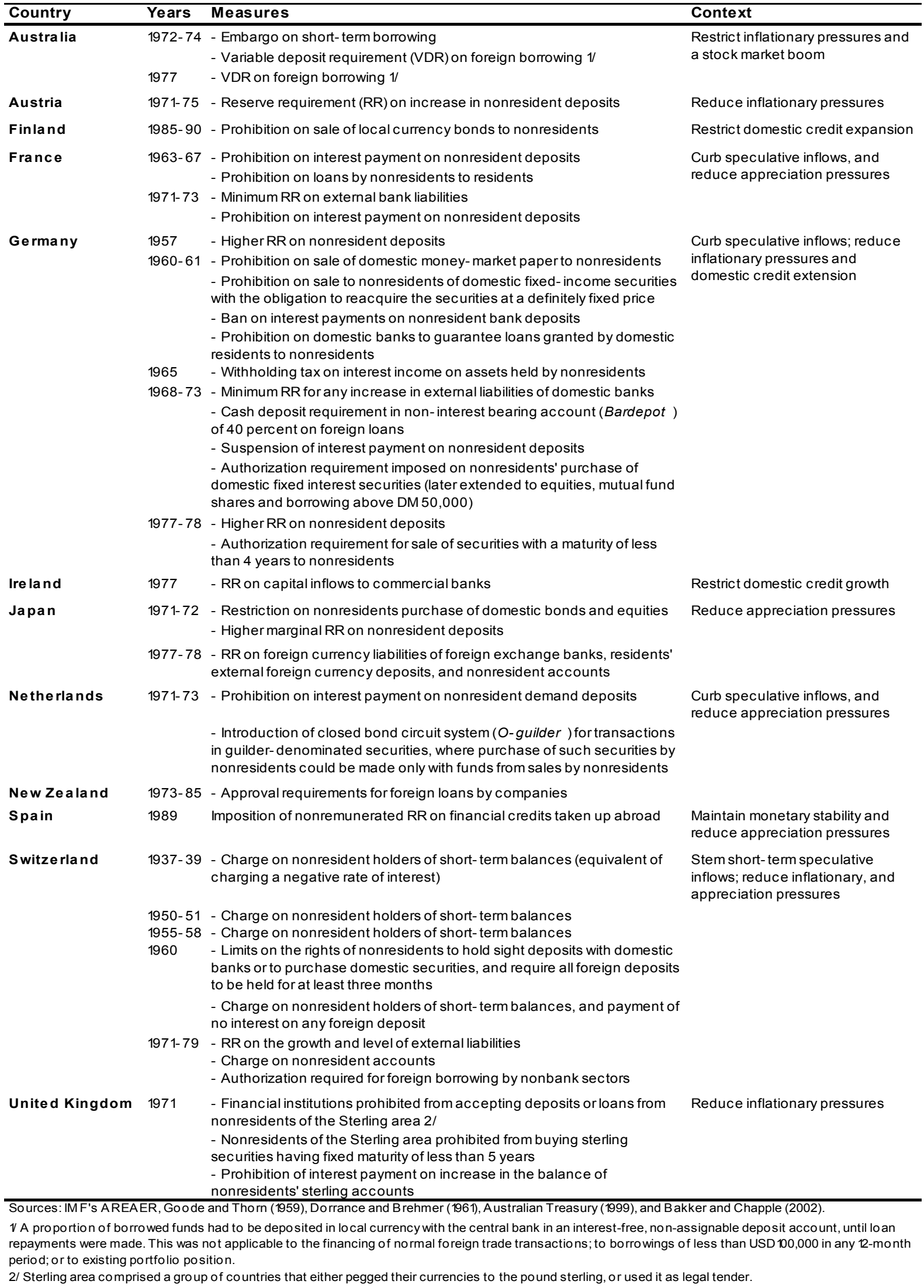

\section{CInternational Monetary Fund. Not for Redistribution}


Figure 7. Net Capital Flows to Selected Countries, 1950-1973
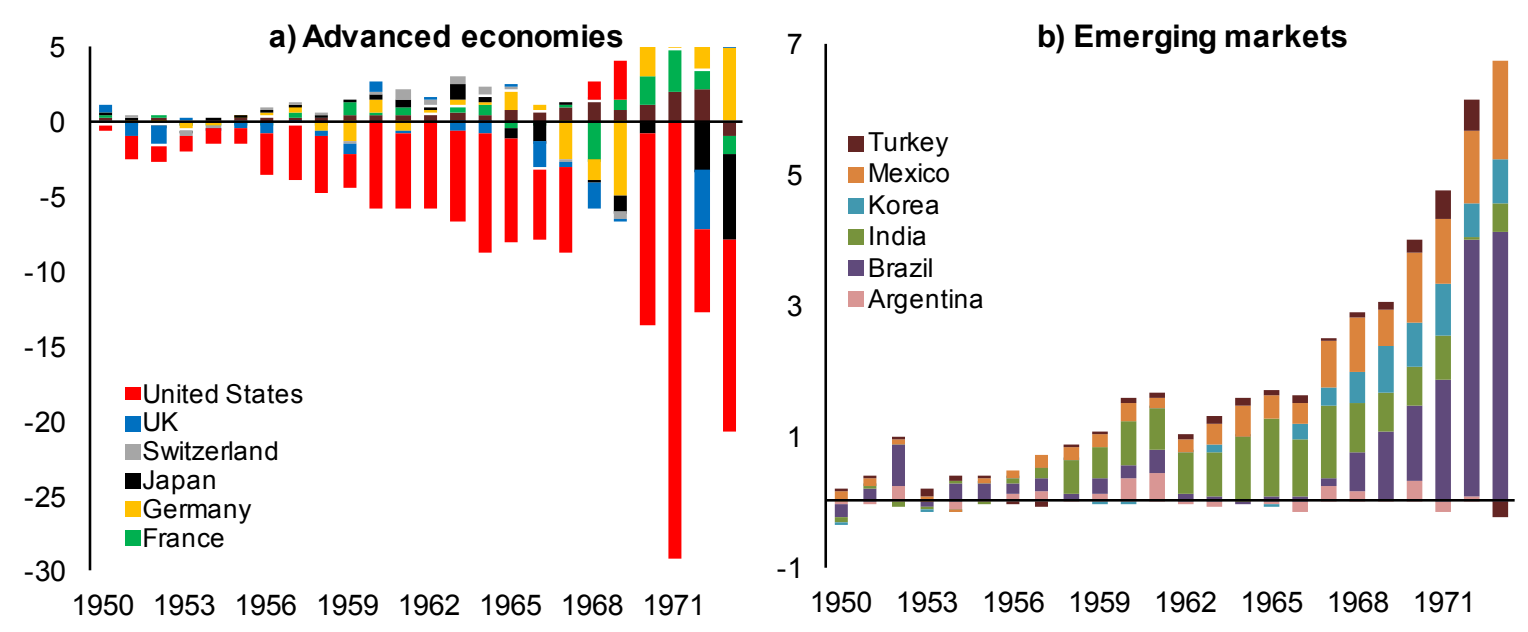

Source: IMF's Balance of Payments Yearbook (various issues).

Note: Statistics exclude reserves and related items, but include net errors and omissions.

By 1974, the US had abandoned its outflow capital controls. Confident that the size and liquidity of US financial markets would always attract investors, American officials henceforth embraced - explicitly and unreservedly — a liberal international regime for private capital flows. The 1973 Economic Report of the President thus noted that "controls on capital transactions for balance-of-payments purposes should not be encouraged and certainly not required in lieu of other measures of adjustment, nor should they become the means of maintaining an undervalued or overvalued exchange rate." 39 The new doctrine also sought to eliminate the Bretton Woods bias of free trade over free capital flows: the 1973 Economic Report went on to argue that the new rules governing the international monetary system should recognize the parallelism between trade in goods and services, and trade in financial assets. Accordingly, when the text of the amended IMF Articles of Agreement was being negotiated in 1978, the US delegation managed to insert the phrase "the essential purpose of the international monetary system is to provide a framework that facilitates the exchange of goods, services, and capital among countries." 40

Interestingly, while advanced countries were changing course, the trend in developing and emerging market economies was the reverse, with greater restrictiveness in the late 1960s and 1970s. ${ }^{41}$ The military coup in Brazil in 1965 marked the turning point in Latin America, which was significantly financially open before then. The new military regime developed an authoritarian, inward-looking model of industrialization, which implied stringent controls on merchandise trade, as well as on capital flows (Quinn, 1997). The model was emulated

\footnotetext{
${ }^{39}$ Economic Report of the President, 1973, p. 128; cited in Helleiner (1994, p. 106).

${ }^{40}$ Cited in Helleiner (1994), who adds the emphasis.

${ }^{41}$ With the exception of offshore centers - though in most such countries, international financial activities (and institutions) are explicitly segmented from the rest of the "real" economy.
} 
broadly by other countries in the region as their own political climate changed. In South Asia, the level of financial openness had matched that of Great Britain - the colonial power - until independence in 1947; but as these countries experimented with inward looking policy frameworks in the late 1950s and 1960s, they became significantly financially closed. In East Asia, countries had been, on average, relatively less financially open than their Latin American peers during the early Bretton Woods period, but several of them further tightened their capital account restrictions in the 1960s and 1970s as they pursued development through active government intervention (e.g., Korea), or ran into balance of payments difficulties (e.g., Thailand). ${ }^{42}$

The restrictions in emerging markets were, again, mostly outflow controls, which were instrumental in meeting budgetary needs through financial repression. Even some of the measures that could be classified as inflow controls because they are likely to discourage inward investment - such as minimum investment periods, or limits on the pace or amounts of repatriation - were intended to prevent a sudden reversal of capital inflows and balance of payments deficits. In fact, until the 1970s, most inflow restrictions in emerging markets took one of two forms: limitations on the amortization and repatriation of nonresidents' investments (to prevent sudden outflows), or designation of specific sectors of the economy in which foreigners were not allowed to invest (in some cases, the set of sectors was sufficiently broad that the measure would likely have limited overall private external borrowing). ${ }^{43}$

\section{Advent of Floating and the Washington Consensus}

In the 1950s and 1960s, the new liberalism had started to gain a sounder footing intellectually as well. In his 1953 essay, for example, Milton Friedman had argued — at that time, heretically - the benefits of floating exchange rates. With their advent in the early 1970s, the "impossible trinity" of monetary autonomy, free capital mobility, and fixed exchange rates was solved by dropping the latter in favor of exchange rate flexibility.

The resulting exchange rate volatility after the collapse of the Bretton Woods system was, however, at odds with the desire for greater integration by European countries that had embarked upon their common currency project with greater urgency. But various crises during its implementation delayed — and at times, temporarily reversed — full capital account

\footnotetext{
${ }^{42}$ East Asia was characterized by different approaches to capital account openness in that period. Some countries, e.g., Hong Kong, Indonesia, and Singapore became less restrictive in the 1970s, while China remained significantly closed.

${ }^{43}$ Beginning in the 1970 s, measures that were more explicitly prudential in nature began to appear. Brazil, for instance, introduced safeguards against excessive use of foreign credits by commercial and investment banks by limiting the foreign obligations that each bank could assume, and by passing on the exchange risk in these transactions to the ultimate borrowers; Venezuela introduced special regulations for foreign banks operating domestically; and Mexico limited banks' foreign currency liabilities from a single nonresident investor (source: various issues of IMF's Annual Report on Exchange Arrangements and Exchange Restrictions (AREAER)).
} 
liberalization. ${ }^{44}$ France is a case in point. Starting in the early 1960 s, France began to liberalize its capital account, and - against the backdrop of a strengthening balance of payments and the desire to make the franc a global currency that could challenge the hegemony of the US dollar-it had removed most capital account restrictions by the end of 1966. But the Paris riots in May 1968 forced the authorities to re-impose outflow controls, invoking for the first time the safeguards clause (which enabled member states to take protective measures when short-term capital movements of exceptional size seriously disrupted the conduct of monetary policy) under the European Community (EC) capital regime. ${ }^{45}$ These restrictions were maintained even as capital inflow measures - a 100 percent marginal reserve requirement on incremental nonresident franc deposits - had to be applied in 1971 to stem flows speculating against dollar devaluation. ${ }^{46}$

The situation reversed with the 1973 oil price shock, which resulted in safe haven flows to the US, necessitating a further intensification of French outflow controls. These outflow controls, which were relatively effective (the on shore-off shore franc interest rate differential reached 5 percent per year) allowed France to pursue more expansionary policies than Germany during the latter half of the 1970s - though the franc was devalued twice: in January 1974, when it left the European "snake," and in March 1976, when it again left the snake less than a year after it had rejoined the mechanism. ${ }^{47}$ Between 1976 and the establishment of the European Monetary System (EMS) in 1979, the franc depreciated by a further 30 percent against the Deutschemark despite successive efforts at tightening outflow restrictions.

Likewise, through the 1970s, Japan sought to influence the value of its currency through the use of capital controls - despite the formal move to floating in February 1973. As mentioned above, when the Yen came under upward pressure because of speculative outflows from the US in 1971, the authorities tightened controls on portfolio inflows (and relaxed outflow restrictions). But when the Yen came under downward pressures following the first oil price shock in October 1973, restrictions on nonresident portfolio bond and equity purchases were eased, while residents were restricted in their purchases of short-term foreign currency securities. In 1977, as the Yen strengthened, the pattern was reversed with restrictions applied more vigorously to discourage capital inflows, and controls on residents' outflows

\footnotetext{
${ }^{44}$ The first concrete articulation of the single currency project was the Werner report (Council-Commission of the European Communities, Report to the Council and the Commission on the Realisation by Stages of Economic and Monetary Union in the Community, 16. 956/II/70, 8 October 1970).

${ }^{45}$ Article 67 of the 1957 Treaty of Rome required member states to progressively abolish between themselves all restrictions on the movement of capital to the extent necessary to ensure the proper functioning of the common market (emphasis added).

${ }^{46}$ The outflow controls were maintained because despite the appreciation pressure against the dollar, the French franc tended to weaken against the Deutschemark (i.e., appreciation pressures on the Mark were greater); see Bakker and Chapple (2002) who detail advanced economy experiences with the use of capital controls.

${ }^{47}$ The "snake" refers to the decision by European Economic Community countries in 1972 to maintain stable exchange rates after the collapse of the Bretton Woods system by preventing exchange rate fluctuations greater than 2.25 percent. The system was in place until March 1979, when it was replaced by the European Monetary System.
} 
were relaxed. Yet again, in 1979, when the Yen came under downward pressure after the second oil price shock, inflow controls were lifted - though, in this instance, outflow controls were not re-imposed. Even the Swiss resorted to restriction in 1978 when they prohibited the purchase of domestic stocks and bonds by foreigners, but terminated the ban in early 1979. In January 1978, the Bundesbank imposed a reserve requirement of 100 percent on the growth of external liabilities to nonresidents, but terminated it five months later.

A major turning point in Continental Europe came with the French President Mitterrand administration's 1983 tournant de la rigueur (i.e., away from inflationary policies and toward a franc fort firmly pegged to the Deutschemark), together with the realization that controls on capital outflows - which had been intensified during the economic crisisdisproportionately penalized middle class investors who were less able than the rich to evade them. Most French outflow controls were thus lifted during 1984-86, with full capital account liberalization achieved by $1990 .^{48}$

This shift in attitude from a country that had long favored capital controls had major repercussions for European and for other advanced economies (Abdelal, 2006). Jacques Delors, who had been Mitterrand's Economics and Finance Minister, went on to become President of the European Commission, where he championed free movement of capital within the single market, culminating in the 1988 European Council Directive to "abolish restrictions on movements of capital taking place between persons resident in Member States" and to "endeavor to attain the same degree of liberalization....in respect of movements of capital to or from third countries." 49 Around the same time, Henri Chavranski, who had been a senior official in the French treasury in the Mitterrand administration, became the chairman of the OECD's Committee on Capital Movements and Invisible Transactions, and from that vantage point helped to expand the Code of Liberalization to include all cross-border capital movements, including short-term flows that had been excluded from the original formulation of the Code. (As recounted below, a third official from the same Mitterrand administration, Michel Camdessus, went on to become the Managing Director of the IMF, where he championed an amendment to the IMF Articles that would give it the mandate to promote capital account liberalization-not just in Europe or among advanced economies, but in emerging markets and developing countries as well.)

Meantime, in the Anglo-Saxon countries, the impetus toward greater financial openness received a further boost in the early 1980s with the Reagan-Thatcher free-market doctrine: the US abjured even foreign currency intervention, and the UK finally liberalized its capital account. Moreover, such liberalism was increasingly incorporated in policy advice to

\footnotetext{
${ }^{48}$ Abdelal (2006) suggests that in championing free capital mobility, the French Minister of Finance, Jacques Delors, was in part motivated by the need to provide Germany a quid pro quo for full monetary union.

${ }^{49}$ EC Council Directive for the implementation of Article 67 of the Treaty (88/361/EEC). The Directive put transfers pertaining to capital movements on the same footing as those for current transactions, though Article 3 of the Directive provides for temporary safeguards, not to be exercised for more than six months, in the face of "short-term capital movements of exceptional magnitude that impose severe strains on foreign exchange markets and lead to serious disturbances in the conduct of monetary and exchange rate policies."
} 
developing and emerging market countries. While capital account liberalization was not a priority of the original "Washington Consensus" (see Williamson, 1990), the idea of subjecting government policies to the discipline of the market was very much in the spirit of the reforms prescribed by the international community to emerging market and developing countries. As Summers (1998) argued "market discipline is the best means the world has found to ensure capital is well used." Thus, as countries pursued trade liberalization under the Washington Consensus, capital account liberalization was seen as part of the process.

But as some emerging market countries liberalized domestic financial markets and outflow controls toward the end of 1970s and early 1980s, they sometimes also swept away the "prudential" inflow measures that were already in place. Chile is a case in point. Until 1981, foreign borrowing by commercial banks required central bank approval, and all foreign borrowing with less than $5 \frac{1}{2}$ year maturity was subject to steep reserve deposit requirements, ranging from 10 percent to 25 percent. These restrictions were, however, removed or significantly reduced once Chile embarked on its financial liberalization program in the early 1980s. The result, as Diaz Alejandro (1985) put it, was goodbye financial repression, hello financial crash - a massive inflow surge (the current account deficit reached 14 percent of GDP), real exchange rate appreciation, and a credit boom (banking system credit to the private sector expanded 40 percent between end-December 1981 and June 1982) - followed by a crash in which, by mid-1983, non-performing loans reached 113 percent of bank capital; much of the banking system had to be nationalized; and GDP contracted 15 percent relative to 1981. Similar experiments in domestic cum external liberalization in Argentina and Uruguay ended equally disastrously. ${ }^{50}$

This experience helped shape policy responses when inflows to emerging markets resumed in the early 1990s (once the Latin American debt crisis had been largely resolved with the 1989 Brady Plan), and led to a marked shift in the preference for longer-term, nondebt flows (Figure 8). In 1989, for example, as the Chilean economy overheated, the central bank tightened monetary policy which, combined with a fall in world interest rates and improved market sentiment, resulted in a surge of capital inflows that further fuelled the economic and financial boom. To reduce the volume of inflows and tilt its composition away from shortterm debt flows, in June 1991 the central bank introduced a 20 percent unremunerated reserve requirement (URR) on foreign borrowing (the reserve requirement applied for the duration of the inflow for maturities of less than a year, but for one year on inflows of longer maturities); minimum stay requirements; regulatory requirements on corporate foreign borrowing; and extensive reporting requirements for banks' capital transactions (Table 3 ). ${ }^{51}$

\footnotetext{
${ }^{50}$ Reported statistics are from Díaz-Alejandro (1985); of course, not all developing and emerging market countries that liberalized subsequently suffered financial crises.

${ }^{51}$ Initially, the URR covered foreign loans (except trade credits), but to prevent circumvention, coverage was later extended to foreign currency deposits, secondary American Deposit Receipts, and foreign direct investment deemed to be of a speculative nature (Ariyoshi et al., 2000). The URR was raised to 30 percent until capital inflows abated in the context of the 1997/98 Asian crisis, at which point the URR was eliminated.
} 
Figure 8. Net Capital Flows to Emerging Markets by Type of Flow, 1970-2013 (in USD bln.)

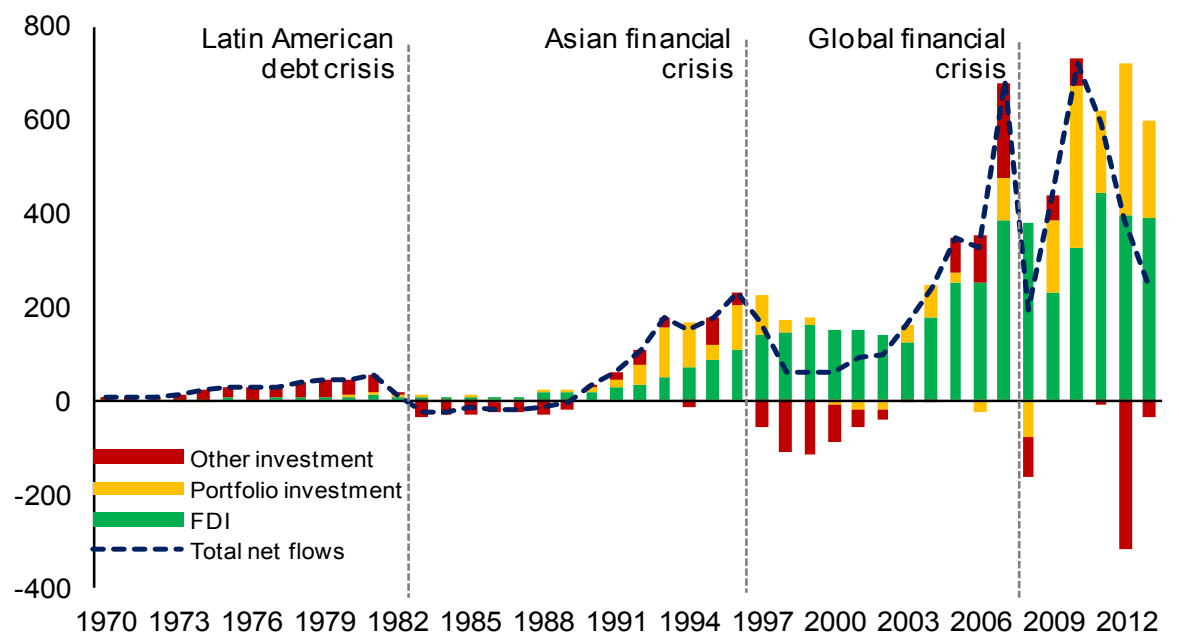

Source: IMF's IFS and WEO databases.

Note: Net capital flows exclude official liabilities of the general government (typically official loans) and foreign exchange reserves. Data are from WEO for 1970-79, and from the IFS for 1980-2013.

Chile was not the only country to experiment with inflow controls in the early 1990s - others included Brazil, Colombia, Malaysia, and Thailand. Yet such measures were not viewed favorably, and the general trend during much of the 1990s was very much toward greater financial openness, culminating in IMF's Managing Director Michel Camdessus' 1995-97 initiative to amend the IMF's Articles, and give it jurisdiction over the capital account in addition to the current account. ${ }^{52}$ Abdelal (2006) quotes an interview with Camdessus:

Exchange controls may help insulate a country's authorities, but only for a very short time. Even the best conceived and effective exchange control system will be circumvented within six months. Speculators and crooks are extremely sophisticated. And then, after a year, exchange controls are effective only against the poor. The French experience of the beginning of the ' 80 s had been extremely convincing for me. I preached on every possible occasion that you cannot trust exchange controls in the long term.

It is noteworthy that the French experience that Camdessus alludes to in the above quote was that of capital outflow controls. The proposed amendment, however, would have given the IMF formal jurisdiction over members' financial regulations - generally prohibiting the

\footnotetext{
${ }^{52}$ Formally, as discussed above, the IMF has jurisdiction over payments for current account transactions rather than jurisdiction over the transactions themselves (which, at Bretton Woods, was to be the purview of the World Trade Organization). However, the proposed amendment to the IMF Articles to cover capital movements would have given jurisdiction over both the associated payments and the underlying capital transactions; direct foreign investment might have been excluded because of political sensitivities. From a financial-stability perspective, the latter exclusion may have had the unfortunate effect of encouraging short-term portfolio flows over (generally more stable) FDI flows.
} 
imposition of new restrictions without its approval — as well as an explicit mandate to promote capital account liberalization; in practical terms, it would have allowed conditionality on capital account restrictions in IMF-supported programs.

But in the end, the amendment was never passed. Opposition came from two quarters. Perhaps surprisingly, the US financial community - voicing its views through the Institute of International Finance (IIF) - opposed the initiative because it potentially gave the IMF too much power, including scope to legitimize capital controls of which it did approve. ${ }^{53}$ At the other end of the spectrum was opposition from emerging market and developing countries, who alarmed by the unfolding East Asian crisis, were concerned that - even with transitional arrangements - the IMF would use this mandate to force premature liberalization on reluctant countries. House Democrats in the US Congress provided the final nail in the amendment's coffin when they threatened to withhold the US quota increase unless the US Treasury withdrew its support for the amendment, which it promptly did. That left only the European countries championing the amendment, and by 1999 the initiative was effectively dead. ${ }^{54}$

That the amendment failed to pass did not absolve the IMF from having to give advice on capital account management. Conceptually, what evolved on liberalization was the "integrated approach" that envisions proceeding through successive, and often overlapping, phases of lifting controls on inflows and outflows, taking into account domestic financial and macroeconomic conditions and policies. ${ }^{55}$ For countries that had already-largely or fullyliberalized, the IMF needed to provide advice on how best to respond to inflow surges. A subsequent Independent Evaluation Office (IEO, 2005) review of IMF reports during the 1990s found that the staff had given advice on how to manage capital flows in 19 episodes (covering 16 countries) out of 27 emerging market economies that experienced large inflows. Of those 19 episodes, countries were counseled to tighten fiscal policy in 12 cases; allow greater exchange rate flexibility in 14 cases; tighten monetary policy and/or sterilize intervention in 17 cases; liberalize outflows in 6 cases; tighten prudential measures in 4 cases; and impose or tighten inflow controls in just 2 cases.

Thus, in contrast to the vision of Keynes and White, policy advice had moved away from viewing inflow controls as an essential policy tool to mitigate potentially destabilizing, speculative inflows. There was also some inconsistency in the approach at the international level after the East Asian Crisis - the usefulness of inflow restrictions as a policy tool was explicitly acknowledged, but still not encouraged or viewed favorably. For instance, a report

\footnotetext{
${ }^{53}$ Moreover, Charles Dallara, the IIF Managing Director noted, "Although capital account openness is in the broad interest of financial institutions, bankers are much more interested in particulate countries, rather than the system as a whole. And the economies that matter most are already mostly open" (Abdelal, 2006).

${ }^{54}$ For the European attitude toward the proposed amendment, see Communication from the Commission to the Council on Amendment to the IMF Articles of Agreement on Capital Movements (SEC 97, 1466, Brussels, 23.07.97).

${ }^{55}$ See Ishii and Habermeier (2002) for details on the integrated approach.
} 
prepared by the Working Group on Capital Flows of the Financial Stability Forum in 2000 noted: ${ }^{56}$

The use of controls on capital inflows may be justified for a transitional period in the face of very strong inflows or as countries strengthen the institutional and regulatory environment in their domestic financial systems, especially if the process of liberalization has not been carried out in a well-sequenced manner. In other words, some measures to discourage capital inflows may be used to reinforce or complement prudential requirements on financial institution and other resident borrowers.

Despite the general disapproval, as capital flows surged to EMEs in mid-2000s, some countries deployed controls on inflows. ${ }^{57}$ Colombia, for instance, imposed a URR on foreign borrowing and portfolio inflows in 2007 (while also limiting the currency derivative positions of banks), and Brazil tightened its foreign exchange tax on inflows in the runup to the crisis in January 2008 (Table 3). In some cases, however, attempts to impose such controls backfired. In Thailand, for example, concerned by the sharp rise of the Thai baht, the central bank imposed a 30 percent URR (with a 10 percent penalty if the funds were withdrawn in less than one year) on all foreign inflows in December 2006. Market reaction to this announcement was strong: the Thai stock market plunged 15 percent in less than one day, with indices in other markets-Malaysia, Singapore, Indonesia, India - declining by 2-3 percent in contagion selling. As the press noted, the episode "evoked memories of the currency crisis nearly a decade earlier ..." even though "the difference was that rather than trying to stop a plunge in the baht, Thailand was acting to stop sharp increases in its currency, which hit a nine-year high against the dollar Monday after rising 16 percent this year." $" 58$ Financial markets thus sent a clear signal that they did not approve of the capital controls - whether on outflows or on inflows, to the point of not even bothering to distinguish between them.

\footnotetext{
${ }^{56}$ Source: Report of the Working Group on Capital Flows, Meeting of the Financial Stability Forum, 25-26 March 2000 (para 115, p. 35; available online at: http://www.financialstabilityboard.org/wpcontent/uploads/r_0004.pdf?page_moved=1).

${ }^{57}$ Abdelal (2006, p. 196-199) suggests that following the Asian financial crisis, the IMF became more cautious about promoting capital account liberalization. This is, however, distinct from adopting or strengthening controls by countries that have already (largely or fully) liberalized their capital accounts.

${ }^{58}$ New York Times, December 19, 2006.
} 
Table 3. Selected Cases of Inflow Controls Tightening in Emerging Market Economies

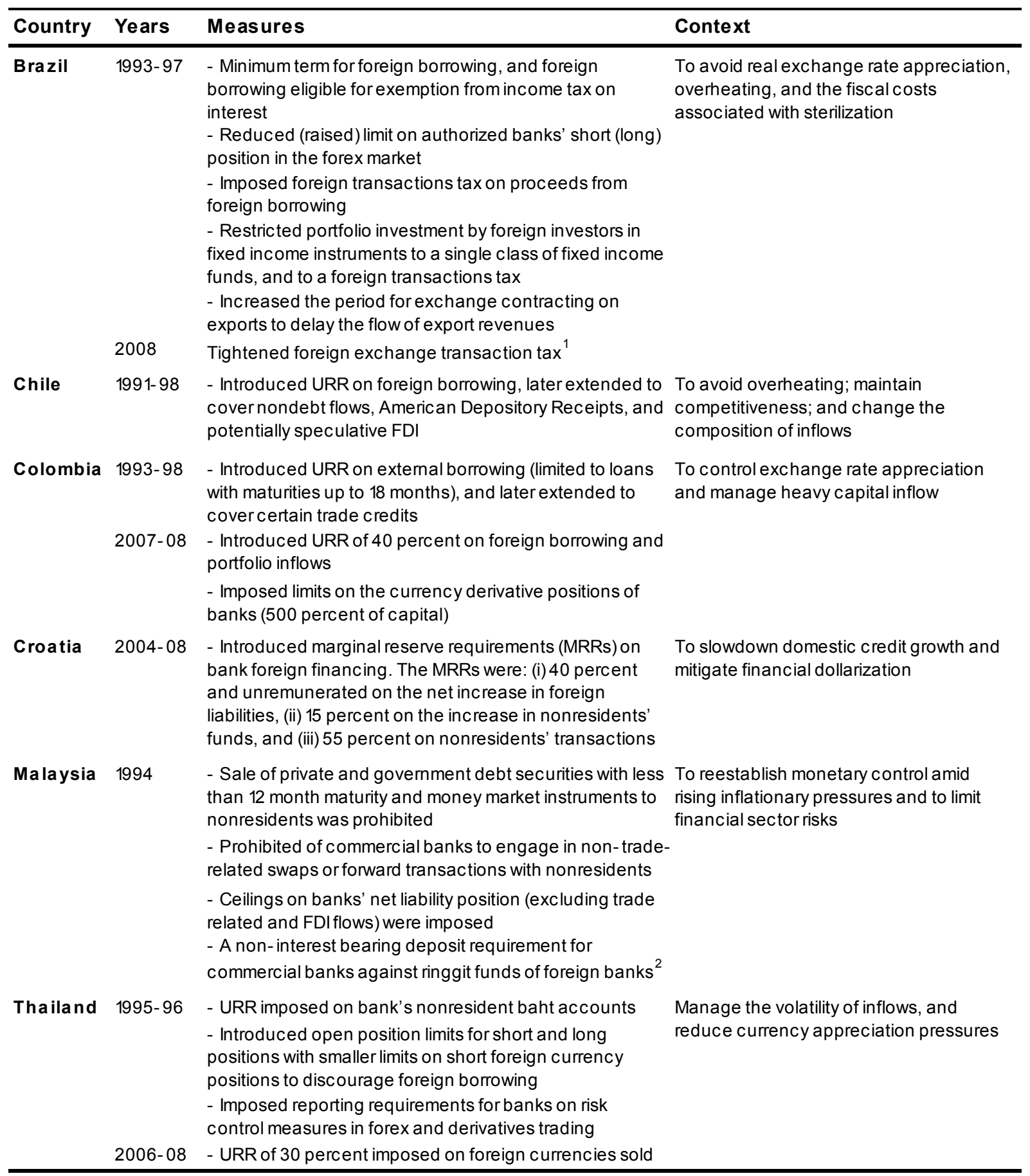

Sources: IMF's AREAER, Ariyoshi et al. (2000), and Magud and Reinhart (2007).

1/ Stated aim of the increase in tax was to raise fiscal revenues.

$2 /$ Subsequently, banks' eligible liability base was redefined to include all foreign inflows, subjecting them to reserve and liquid asset requirements. 


\section{E. The Global Financial Crisis and its Aftermath}

The global financial crisis was a rude reminder that not all borrowing and lending decisions are rational, that markets can become over exuberant, and that unfettered flows can result in excessive volatility. With the Lehman collapse in September 2008, capital flows suddenly reversed from emerging markets, dropping by a staggering US\$ 240 billion in net terms in one quarter (Figure 9). Emerging Europe - which was the most financially open in the runup to the crisis - was hit the hardest, with net flows falling by about US\$ 150 billion between the last two quarters of 2008.

Figure 9. Net Capital Flows to Emerging Markets, 2000Q1-2013Q4 (in USD bln.)

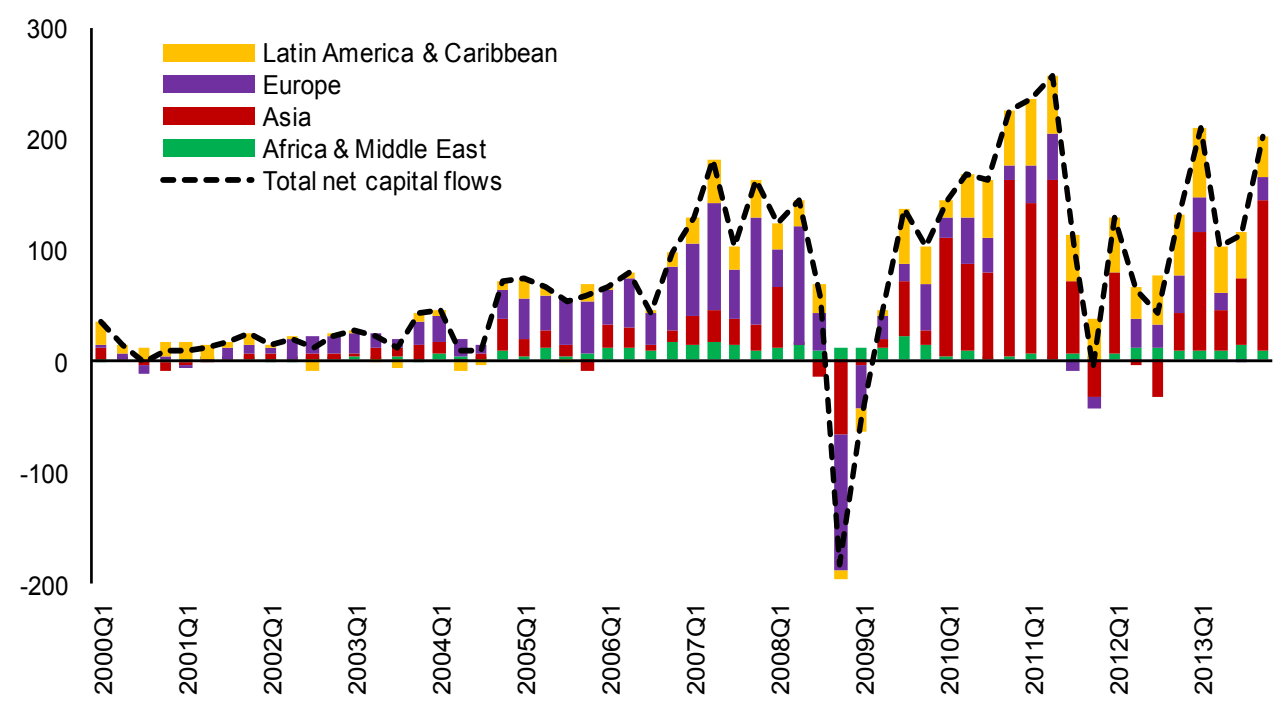

Source: IMF's IFS database.

Note: Flows exclude official liabilities of the general government (typically official loans) and foreign exchange reserves.

By mid-2009, however, flows to emerging markets had rebounded sharply against the backdrop of accommodative monetary policies in advanced countries, and their own strong growth prospects. In an effort to manage the macroeconomic and financial-stability risks of the inflow surge, several countries adopted measures that either directly targeted inflows through the imposition of capital controls, or indirectly influenced them through the use of (currency-based) prudential measures (Table 4). Paralleling developments on the policy front were advances in theoretical models, which established that - due to externalities - the competitive equilibrium will typically be characterized by excessive, and excessively risky, foreign borrowing. The direct implication of these models is that government intervention in the form of capital controls (calibrated to the riskiness of the liabilities) will be welfareimproving (Jeanne and Korinek, 2010; Korinek, 2011; Bianchi, 2011).

The adoption of these policy measures brought capital controls back in the spotlight, making Einzig's (1934) characterization apposite: 
Moreover, it may well be asked whether we can take it for granted that a return to freedom of exchanges is really a question of time. Even if the reply were in the affirmative, it is safe to assume that after a period of freedom the regime of control will be restored as a result of the next economic crisis.

Confronted with the task of policy advice to emerging markets on how to cope with the challenges posed by the large capital inflows, the IMF produced a series of research and policy papers (Ostry et al., 2010, 2011, 2012a; IMF, 2010a, 2011a, 2011b, 2011c, 2012b)culminating in the IMF's Institutional View on the Liberalization and Management of Capital Flows (IMF, 2012a) - which not only explicitly acknowledged that controls on inflows could form a legitimate part of the policy toolkit, but also established that currencybased prudential measures, commonly considered to be superior to capital controls on efficiency grounds, were often economically indistinguishable from capital controls. Crucially, the Institutional View recognizes that while capital flows can have substantial benefits, they also carry risks and that "there is no presumption that full liberalization is an appropriate goal for all countries at all times." As regards capital controls, it acknowledges that "in certain circumstances, capital flow management measures can be useful. They should not however substitute for warranted macroeconomic adjustment." ${ }^{, 59}$ Moreover, for financialstability purposes, the Institutional View envisages that capital controls could be maintained over the longer term (provided that no effective nonresidency-based measure is available), though it also notes that this should not substitute for efforts to improve supervision of the financial sector. ${ }^{60}$

The IMF papers helped spark a wider debate in both policy and academic circles about the appropriate role of capital controls, and the optimal degree of capital account liberalization. Some critics vociferously opposed the IMF's stance (e.g., Olson and Kim, 2013), while others struck a more cautious tone - preferring orthodox measures over capital controls to manage capital inflows (e.g., Caruna, 2011; De Gregorio, 2014). Underlying both attitudes, however, was a strong conviction that capital controls are costly, pervasive, and ineffective.

\footnotetext{
${ }^{59}$ In order to encompass both capital controls and macroprudential measures that affect capital flows, the IMF introduced the nomenclature "capital flow management (CFM)" measures. Capital controls are always CFMs, but whether a prudential measure is a CFM depends on whether it was imposed in order to influence the volume of cross-border flows; the label CFM does not have legal status within the IMF.

${ }^{60}$ The process of arriving at an institutional view that could command the consensus of the IMF membership was contentious - in part because an initial staff paper (IMF, 2010b) proposed that the envisaged guidelines could form formal surveillance "principles for the guidance of members." A subsequent paper (IMF, 2011b), however, clarified that the guidelines would only be used for staff policy advice.
} 
Table 4. Selected Cases of Post-Global Financial Crisis Measures to Limit Capital Inflows

\begin{tabular}{|c|c|c|}
\hline Country & Year & Measures \\
\hline Brazil & 2009- 12 & $\begin{array}{l}\text { Tax of } 2 \text { percent levied on foreign portfolio equity and fixed income inflows in October } 2009 \text {. The tax rate } \\
\text { was gradually raised to } 6 \text { percent, and extended to cover other sources of foreign flows such as the } \\
\text { issuance of depository receipts into local equities; borrowing abroad with maturity less than one-year (later } \\
\text { tightened to maturity less than two, three, and five years); and notional amount of FX derivatives. URR of } 60 \\
\text { percent on banks' gross FX positions beyond USD } 3 \text { bln. (later tightened to USD } 1 \text { bln.) was also levied. }\end{array}$ \\
\hline Costa Rica & 2014 & $\begin{array}{l}\text { Activated for a period of up to } 6 \text { months an increase in the income tax rate (from } 8 \text { to } 33 \text { percent) on interest } \\
\text { earned on investments in fixed income assets issued by private sector entities to nonresidents; and } \\
\text { established URR for new investments in these financial instruments. }\end{array}$ \\
\hline Indonesia & $2010-11$ & $\begin{array}{l}\text { Imposition of a one- month minimum holding period on central bank bonds for all investors; limit on the daily } \\
\text { balance of banks' short- term external debt to } 30 \text { percent of capital; reserve requirement on deposit } \\
\text { accounts in foreign exchange raised from } 1 \text { to } 5 \text { percent. }\end{array}$ \\
\hline Korea & $2010-11$ & $\begin{array}{l}\text { The maximum limits on banks' FX derivative contracts set at } 50 \text { percent (domestic banks)and } 250 \text { percent } \\
\text { (foreign bank branches) of bank capital in the previous month. Restoration of a } 14 \text { percent withholding tax } \\
\text { on interest income on nonresident purchases of treasury and monetary stabilization bonds. }\end{array}$ \\
\hline Peru & 2010- 11 & $\begin{array}{l}\text { Extended a } 60 \text { percent reserve requirement for new foreign holders of debt with maturity up to three years. } \\
\text { Extended the income tax rate of } 30 \text { percent to all nonresident gains on financial derivatives transactions. }\end{array}$ \\
\hline Thailand & 2010 & $\begin{array}{l}\text { Restoration of a } 15 \text { percent withholding tax on nonresidents' interest earnings and capital gains on new } \\
\text { purchases of government bonds. }\end{array}$ \\
\hline Uruguay & 2012 & $\begin{array}{l}\text { Reserve requirement of } 40 \text { percent (later raised to } 50 \text { percent) introduced on new foreign purchases of } \\
\text { central bank notes and central government securities. }\end{array}$ \\
\hline
\end{tabular}

\section{UNRAVELING THE THINKING BEHIND INFLOW CONTROLS}

Why do inflow controls evoke such apprehension? From the discussion above, it is abundantly clear that notwithstanding the general trend toward financial liberalization in the latter half of last century, capital controls on inflows were occasionally adopted by advanced countries to curb speculative inflows in the interwar and Bretton Woods periods, but also afterwards. That these countries abandoned the use of capital controls for prudential purposes was - at least in the case of Britain and the United States - partly driven by the desire to be global financial centers, and in the case of Europe, to enhance regional economic integration.

The historical review, in our view, offers three key explanations why inflow controls have a bad name. First, with the rise of free market ideology in the 1980s and 1990s, it appears that capital inflow controls became inextricably linked with outflow controls. Traditionally, the latter were more prevalent, more stringent, and typically associated with autocratic regimes, financial repression, and financial crises. They were (and are) thus viewed highly unfavorably. In fact, simple cross-country correlation between capital controls and an index reflecting the intensity of the autocratic regime in the country suggests a positive and statistically significant association between such regimes and the presence of capital controls — which is twice as large for outflow controls then for inflow controls (Figure 10). ${ }^{61}$

\footnotetext{
${ }^{61}$ These countries may also have greater need for (outflow) controls because of weak macroeconomic management and poor economic policies (and not just because of autocratic regimes) - but poor economic policies, and the need for outflow controls to support them, is part of the reason why capital controls, including on inflows, have a bad name.
} 
(Likewise, the correlation between capital controls and an index reflecting democracy is significantly negative - suggesting lower controls in more democratic regimes - but the relationship is weaker for inflow controls as compared to outflow controls.) Thus, it can be argued that more liberalized economies shunned the use of inflow controls as a short-term policy tool out of fear of being viewed as market unfriendly and institutionally weak. ${ }^{62}$

Figure 10. Capital Controls and Polity, 1950-2010

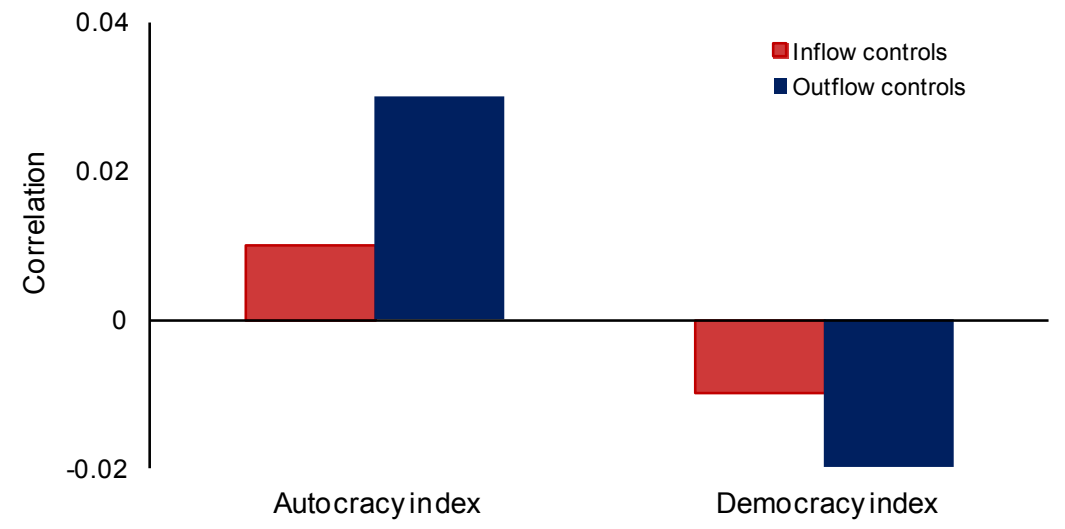

Source: Authors' estimates based on data from IMF's AREAER, and the Center for Systemic Peace's Polity IV project. Note: Sample is that used in Figure 6. Correlation is the estimated coefficient obtained from a country-fixed effects regression of capital controls on the respective indices (with standard errors clustered by country). All correlations are statistically significant at the 5 percent level.

Most of the other criticisms levied against inflow controls are actually much more pertinent to outflow controls. ${ }^{63}$ It is often argued, for instance, that inflow controls are highly persistent and pervasive. But that is generally true for outflow controls, when to prevent capital flight, authorities often resort to heavy-handed measures that are broad-based, and are only gradually removed as the domestic economy stabilizes. ${ }^{64}$ The nature of (ad hoc) restrictions to control inflows is different - typically being taxes on certain types of (more risky) flows; withholding taxes on nonresident investments; or higher reserve requirements for nonresident investments. Such measures are easy to reverse, and are typically removed when the tide turns (as is evident from the experience of, e.g., Brazil, Chile, Colombia, Indonesia, and Peru) ${ }^{65}$ In addition, there is no evidence that inflow measures send a "bad signal" that deters

\footnotetext{
${ }^{62}$ A case in point is the recent imposition of inflow controls by Brazil, which ignited strong disapproval from investors, who viewed the measures as harmful, a 'blunt instrument,' and reminiscent of the widespread capital controls in Latin America during the period of hyperinflation and weak economic performance in the 1980s. See, for example, "Brazil 'Bizarre' Taxes May Undo Gains, Federated Says," Bloomberg, November 19, 2009; "Capital Controls Roil Latin America Bond Markets by Evoking '80s,” Bloomberg, January 19, 2011.

${ }^{63}$ In fact, Governor Carstens' speech cited in the introduction was about how countries should cope with capital inflows, but tellingly, his only real criticism of capital controls concerns the use of outflow controls.

${ }^{64}$ Dornbusch (1998) notes that controls on outflows are unlikely to be effective unless extremely intense and broad-based, because anything less would be insufficient to prevent capital flight when investors fear a prospective collapse of asset prices and financial institutions.

${ }^{65}$ As discussed in Section II, temporary capital controls imposed by advanced countries to prevent speculative capital inflows in different periods were also reversed when the inflow surge abated. It is generally more
}

(continued...) 
foreign investors from reinvesting in these countries in later years. Again, the signaling concern - although often given as an argument against inflow controls - is also arguably more valid for restrictions on outflows, which may shake investor confidence, and lead to a "once bitten-twice shy" attitude toward the domestic market.

Inflow controls are also considered to be ineffective; yet ample evidence exists that they are successful in titling the composition of flows toward less risky and longer-maturity flows (the evidence on currency appreciation is more mixed; see, e.g., Magud and Reinhart, 2007; Ostry et al., 2015) — which strengthens the case for their use as prudential instruments. ${ }^{66}$ By contrast, anecdotal evidence (see, for instance, Michel Camdessus' quote above), and formal studies suggest that capital outflow controls tend to be ineffective in preventing a crisis by slowing down the drain of foreign exchange reserves and permitting time for corrective policies (e.g., Edwards, 1999; Edison and Reinhart, 2001). ${ }^{67}$

The upshot is that much of the criticism against inflow controls seems to be "guilt by association" with outflow controls. Thus, when emerging markets attempted to liberalize their capital accounts in the 1980s and 1990s, they did not distinguish much between inflow and outflow controls, and often jettisoned both at the same time (as is evident from Figure 6). That the distinction between the two types of restrictions got blurred is even more apparent from the debates that surfaced in the aftermath of the Asian financial crisis, when calls for reining in speculative capital inflows to preserve financial-stability and prevent financial crises (e.g., Bhagwati, 1998; Cooper, 1999; Eichengreen, 1998; Rodrik, 1998, Stiglitz, 2000) were overshadowed by the more contentious debate on capital outflow controls imposed by Malaysia (see, e.g., Krugman, 1998, 1999; Wade and Veneroso, 1998). Yet, many of those who favored unrestricted capital mobility, and vehemently argued against capital outflow controls, preferred a "system of preventive capital controls that limits the extent of capital inflows in the first place or, at least, structures their maturities" (Dornbusch, 1998).

This is not to say that inflow controls are not costly (or that emerging markets may not benefit from foreign capital — especially in the form of foreign direct investment). ${ }^{68}$ Controls

difficult to remove outflow controls because the pent up demand by non-residents seeking to repatriate their blocked funds (if controls have been imposed under crisis conditions) and by residents to invest abroad, might precipitate a balance of payments crisis.

${ }^{66}$ In fact, one reason why they are unpopular with market participants is because they are effective, and increase the cost of investment in the domestic economy. Mohammad El-Erian (former Chief Executive of PIMCO-a global investment management firm), for instance, notes that inflow controls "do exactly what they are intended to do: put sand in the market... We think twice, or three times" (source: "Capital—Just in Case," The

Economist, October 12, 2013). But this is an argument for-rather than against - the use of inflow restrictions.

${ }^{67}$ The evidence on outflow controls for 'curative' reasons-i.e., during a crisis to limit capital flight and a free fall in the currency - is mixed (see, e.g., Edwards, 1999; Edison and Reinhart, 2001; and Magud and Reinhart, 2007). That the evidence on the effectiveness of outflow controls is much weaker is one plausible reason why some studies using aggregate indicators of capital account openness find that countries with greater restrictions have a higher likelihood of experiencing a currency crisis (e.g., Glick et al., 2006).

${ }^{68}$ Evidence on the benefits of capital account liberalization is mixed, though most studies tend to find that FDI is beneficial for growth while imposing few financial-stability risks (see, e.g., Ghosh et al., 2016). 
may be administratively burdensome, distortionary, encourage regulatory arbitrage, hurt small domestic businesses more than large firms, damage liquidity, and encourage rentseeking - but it is not clear that these critiques apply any less to other policy tools often touted as superior to inflow controls (such as prudential measures or fiscal instruments). Even the more recent "spillover" concerns from the imposition of short-term inflow controls (e.g., Forbes et al., 2012) may be no less relevant for other policy instruments (see, e.g., Danisewicz et al., 2015). ${ }^{69}$ Lately, inflow controls have also been suspected of being used to vitiate multilaterally-warranted external adjustment - but this concern is mainly relevant for a handful of large economies and, by itself, does not explain why countries that are considering imposing inflow controls (as opposed to their trading partners) might have misgivings about doing so (unless they are worried about retaliation).

A second plausible reason for the resistance to adopt inflow controls is that capital account restrictions are often associated with current account restrictions. This is because, historically, the most common form of capital controls was exchange restrictions that impeded the movement of both goods and capital. ${ }^{70}$ As countries embraced greater trade liberalization, in contrast to the Keynes-White thesis, they viewed capital controls as incompatible with free trade rather than as aiding free trade. Growing internationalization of commercial activity, for instance, by multinational corporations, also made it more difficult to enforce capital account restrictions without also having an impact on current transactions. ${ }^{71}$ Capital account restrictions were thus abolished along with current account restrictionsalthough the former was not part of the original "Washington Consensus," as noted by Williamson (1990). This trend was further accentuated by the rise of regional trade agreements and bilateral investment treaties (for example, those with the US) that increasingly incorporated clauses prohibiting the adoption of any types of capital controls (except under highly exceptional circumstances). ${ }^{72}$

Finally, the rise of free market ideology in itself considered all government intervention as inherently bad: where market failure was found to be extensive, it was considered to be less serious than state failure that was to replace it (Cappie, 2002). Hence capital controls, traditionally viewed as instruments to fine-tune the economy (since part of their justification under the "trilemma" is that they give policy autonomy), became discredited more generally.

\footnotetext{
${ }^{69}$ Traditionally, spillover concerns were associated more with capital outflow controls because of the risk of contagion and speculative attacks elsewhere. In the context of inflow controls, Ostry et al. (2012b) argue that the existence of spillovers by itself does not preclude the use of such policies. If policies in one country, however, exacerbate existing distortions in other countries, and it is costly for other countries to respond, then multilateral coordination of policies is beneficial.

${ }^{70}$ Indeed, so much so, that the entry for capital controls in the subject index in the official IMF Historian's first history of the IMF reads "capital movements, control of,- -see exchange control" (Horsefield, 1969, p. 643).

${ }^{71}$ Multinationals may be able to evade controls through, for instance, transfer pricing or inter-company loans. Preventing this evasion may require such heavy regulation as to have at least some adverse impact on genuine current transactions; on evidence that large, non-financial corporates may be acting as financial intermediaries in emerging markets that have capital controls, see Caballero et al. (2015), and Shin and Zhao (2013).

${ }^{72}$ See Gallagher $(2010,2013)$ for a discussion on the provisions related to capital controls in trade and investment treaties.
} 
This is, however, not to say that emerging markets became entirely oblivious to the vagaries of capital flows, but they attempted to rely on the more benign-sounding - also viewed as more market-friendly - "macroprudential measures" to tackle the financial-stability risks posed by capital inflows. Yet, for some of these measures, especially, those related to foreign currency transactions, the ultimate effect on capital flows is economically largely indistinguishable to that of more direct capital controls (Ostry et al., 2011, 2012a; IMF, 2012a). That the use of such currency-based measures has increased notably since the East Asian financial crisis, and tends to move with the capital flow cycle of emerging markets (Figures 8 and 11), suggests that countries may be viewing these measures as a substitute for traditional inflow controls (that were imposed for financial-stability purposes). But if this is indeed the case, then it is merely a re-branding of capital controls, confirming that it is the negative connotation associated with the word "controls" that is the problem.

Figure 11. Foreign Currency-Related Prudential Measures in Emerging Market Economies

a) Reserve Requirements 1984Q1-2011Q4

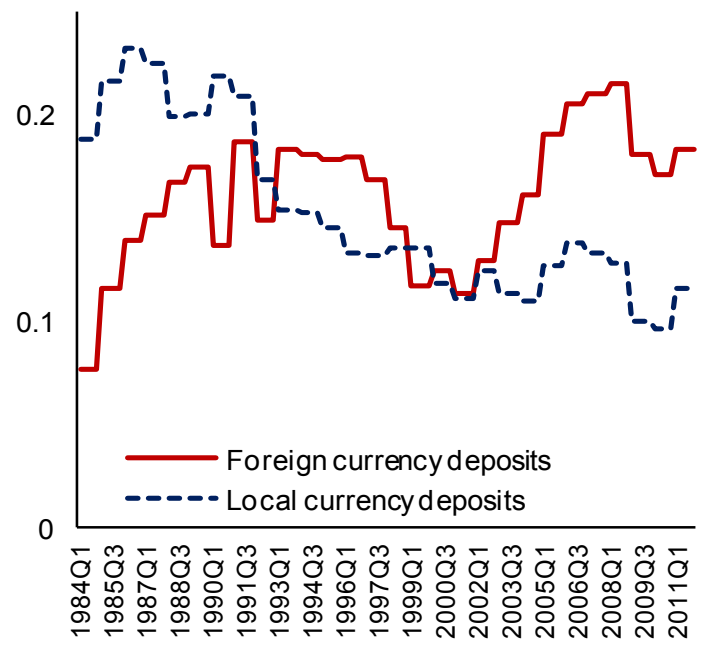

b) Restrictions on local lending in foreign exchange 1995-2013

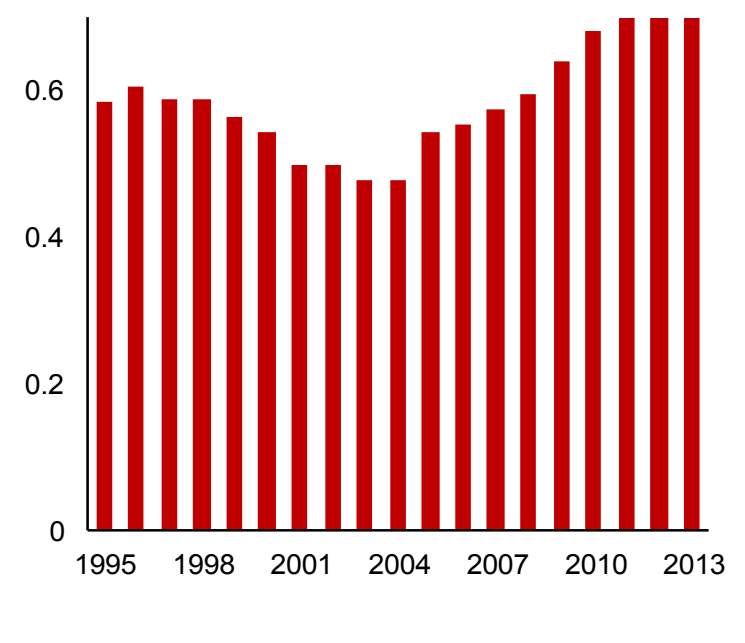

Sources: Federico, Vegh, and Vuletin (2014), and IMF's AREAER (various issues).

Note: Panel [a] presents the yearly average of reserve requirements on demand, savings, and term deposits in emerging markets. Panel [b] presents the yearly average of a binary variable (one indicating the presence of a restriction, zero otherwise) for emerging markets.

\section{Conclusion}

This paper examines why capital controls on inflows have a "bad" name by delving into historical record dating back to the gold standard era - tracing both the use of capital controls and how thinking about them has evolved. Throughout history, boom-bust cycles in capital flows have been a recurring theme, and thinking with regards to capital controls has tended to be influenced by experience in the previous years. The dangers of unfettered capital mobility were not lost to the advanced countries as they pursued their own domestic and external financial liberalization in the latter half of the last century, and they often resorted to temporary capital controls as preventive measures to restrict speculative inflows. 
Our reading of the history yields several conjectures why inflow controls now evoke such visceral opposition. The simplest explanation is that, in the minds of many, inflow and outflow controls have become inextricably linked. Traditionally, the latter were more prevalent, more stringent, and typically associated with autocratic and repressive regimes preventing capital flight; governments trying to prop up failed macroeconomic policies; and financial crisis. The word "controls" thus brings to mind outflow controls, and inflow measures are often damned by this "guilt by association." This is also obvious from some of the typical criticisms on inflow controls, which are actually much more pertinent to outflow controls (for instance, that they are persistent and pervasive; encourage poor macroeconomic policies; and are ineffective). Thus, when countries embraced more market-friendly policies, and liberalized their capital accounts in the 1980s and 1990s, they often jettisoned both outflow and inflow controls at the same time, without fully taking into account prudential considerations.

Likewise, capital account restrictions are often associated with current account restrictions because, historically, the most common form of capital control were exchange restrictions that impeded the movement of both goods and capital. As countries aspired to achieve greater trade integration, capital controls came to be viewed as incompatible with free trade rather than as aiding free trade (which was Keynes' and White's thesis). More generally, capital controls became associated with attempts at fine-tuning the economy (since part of their justification is that they give policy autonomy), which itself became discredited after the stagflationary 1970s - paving the way for the free market ideology that was highly prevalent till the global financial crisis.

Inflow controls thus appear to have an undeservedly bad name. While they are not a flawless instrument to manage the macroeconomic and financial-stability risks associated with capital inflows, there is no reason to believe that they are inherently worse or costlier than any other policy measure. The debate on using inflow controls to tame the risks associated with fickle capital flows should not be cast as all-or-nothing - rather their pros and cons need to be assessed in light of the particular circumstances facing the country, and weighed against the availability, and costs and benefits of other policy tools. Otherwise, like all prejudices, those against inflow controls may result in inefficient choices and suboptimal outcomes. 


\section{REFERENCES}

Abdelal, R., 2006, "Writing the Rules of Global Finance: France, Europe, and Capital Liberalization," Review of International Political Economy, 13 (1): 1-27. , 2007, Capital Rules (Cambridge, MA: Harvard University Press).

Ariyoshi, A., K. Habermeier, B. Laurens, I. Ötker-Robe, J. Canales-Kriljenko, and A. Kirilenko, 2000, Capital Controls: Country Experiences with their Use and Liberalization, IMF Occasional Paper 190 (Washington DC: International Monetary Fund).

Australian Treasury, 1999, "Australia's Experience with the Variable Deposit Requirement," Economic Roundup, Winter: 45-56.

(http://archive.treasury.gov.au/documents/193/HTML/docshell.asp?URL=round5.asp)

Bakker, A., and B. Chapple, 2002, Advanced Country Experiences with Capital Account Liberalization, IMF Occasional Paper 214 (Washington DC: International Monetary Fund).

Bhagwati, J., 1998, “The capital myth. The Difference between Trade in Widgets and Dollars" Foreign Affairs, 77 (May/June): 7-12.

Bianchi, J., 2011, "Overborrowing and Systemic Externalities in the Business Cycle," American Economic Review, 101 (7): 3400-3426.

Bloomfield, A., 1938, "The Foreign Trade Doctrines of the Physiocrats" American Economic Review, 28 (4): 716-735.

, 1950, Capital Imports and the American Balance of Payments, 1934-39 (Chicago: University of Chicago Press).

, 1968, "Patterns of Fluctuation in International Investment before 1914,"

Princeton Studies in International Finance No. 21 (Princeton: International Finance Section, Department of Economics).

Boughton, J., 2002, "Why White, Not Keynes? Inventing the Post-War International Monetary System,” IMF Working Paper WP/02/52 (Washington DC: International Monetary Fund).

Brocard, L., 1902, Les Doctrines Economiques et Sociales du Marquis de Mirabeau (Paris: V. Giard et E. Briere).

Brown, B., 1987, The Flight of International Capital: A Contemporary History (London: Croom Helm). 
Caballero, J., U. Panizza, and A. Powell, 2015, "The Second Wave of Global Liquidity: Why Are Firms Acting Like Financial Intermediaries?” CEPR Discussion Paper No. DP10926 (London: Centre for Economic Policy Research).

Cappie, F., 2002, Capital Controls: A 'Cure’ Worse than the Problem? (London: The Institute of Economic Affairs).

Caruna, J., 2011, "Capital Flows to the Emerging Market Economies: A Perspective on Policy Challenges," speech delivered at the $46^{\text {th }}$ SEACEN Governors' Conference, Colombo, 24-26 February 2011. (http://www.bis.org/speeches/sp110307.htm).

Cooper, R., 1999, "Should Capital Controls be Banished?" Brookings Papers on Economic Activity, 30 (1): 89-142.

Crabbe, L., 1989, “The International Gold Standard and U.S. Monetary Policy from World War I to the New Deal," Federal Reserve Bulletin, 75 (6): 423-440.

Danisewicz, P., D. Reinhardt, and R. Sowerbutts, 2015, “On a Tight Leash: Does Bank Organizational Structure Matter for Macroprudential Spillovers?” Bank of England Working Paper 524 (London: Bank of England).

De Gregorio, J., 2014, "Capital Flows and Capital Account Management," in What Have We Learned? Macroeconomic Policy after the Crisis, eds. G. Akerlof, O. Blanchard, D. Romer, and J. Stiglitz (Cambridge, MA: The MIT Press): 271-288.

Diaz-Alejandro, C., 1985, "Good-bye Financial Repression, Hello Financial Crash," Journal of Development Economics, 19 (1-2): 1-24.

Dornbusch, R., 1998, "Capital Controls: An Idea Whose Time is Past in Should the IMF Pursue Capital-Account Convertibility," Essays in International Finance 207, Princeton University.

Dorrance G., and E. Brehmer, 1961, "Controls on Capital Inflow: Recent Experience of Germany and Switzerland," IMF Staff Papers, 8: 427-438.

Edwards, S., 1999, “How Effective Are Capital Controls?” Journal of Economic Perspectives, 13 (4): 65-84.

Eichengreen, B., 1992, Golden Fetters (New York: Oxford University Press). , 1998, “Capital Controls: Capital Idea or Capital Folly?” mimeo, University of Berkeley, California (http://eml.berkeley.edu/ eichengr/policy/capcontrols.pdf).

Einzig, P., 1934, Exchange Control (London: Macmillan). 
, 1970, The History of Foreign Exchange (London: Macmillan).

Fanno, M., 1939, Normal and Abnormal International Capital Transfers (Minneapolis: University of Minnesota Press).

Federico, P., C. Vegh, and G. Vuletin, 2014, "Reserve Requirement Policy over the Business Cycle,” NBER Working Paper 20612 (Cambridge, MA: NBER).

Feis, H., 1965, Europe: The World's Banker (New York: Norton).

Fleming, J., 1962, "Domestic Financial Policies Under Fixed and Under Floating Exchange Rates," IMF Staff Papers, 9 (3): 369-379.

Forbes, K., M. Fratzscher, T. Kostka, and R. Straub, 2012, "Bubble Thy Neighbor: Portfolio Effects and Externalities from Capital Controls," NBER Working Paper 18052 (Cambridge, MA: National Bureau of Economic Research).

Galati, G., and R. Moessner, 2014, "What Do We Know about the Effects of Macroprudential Policy?” DNB Working Paper No. 440 (Amsterdam: De Nederlandsche Bank).

Gallagher, K., 2010, "Policy Space to Prevent and Mitigate Financial Crises in Trade and Investment Agreements," G-24 Discussion Paper Series No. 58 (Geneva: United Nations Conference on Trade and Development).

, 2013, "Safeguarding United States' Trade and Investment Treaties for Financial Stability," Global Economic Governance Initiative Policy Brief Issue 1 (Boston: Boston University).

Ghosh, A., J. Ostry, and M. Qureshi, 2016, "Why Do Capital Inflow Surges End in Tears?" American Economic Review Papers and Proceedings, forthcoming.

Ghosh, A., M. Qureshi, and N. Sugawara, 2014, "Regulating Capital Flows at Both Ends: Does it Work?” IMF Working Paper WP/14/188 (Washington DC: International Monetary Fund).

Glick, R., X. Guo, and M. Hutchinson, 206, “Currency Crises, Capital Account Liberalization, and Selection Bias," The Review of Economics and Statistics, 88 (4): 698-714.

Gold, J., 1962, The Fund Agreement in the Courts (Washington DC: International Monetary Fund). 
Goode, R., and R. Thorn, 1959, "Variable Reserve Requirements Against Commercial Bank Deposits," IMF Staff Papers, 7 (1): 9-45.

Goodman, J. B., and L. Pauly, 1993, “The Obsolescence of Capital Controls? Economic Management in an Age of Global Markets" World Politics, 46 (1): 50-82.

Edison, H., and C. Reinhart, 2001, “Stopping Hot Money," Journal of Development Economics, 66 (2): 533-553.

Helleiner, E., 1994, States and the Re-emergence of International Finance: From Bretton Woods to the 1990s (Ithaca: Cornell University Press).

Helleiner, E., 2015, “Controlling Capital Flows 'At Both Ends': A Neglected (But Newly Relevant) Keynesian Innovation from Bretton Woods," Challenge, 58 (5): 413-427.

Hobson, C., 1914, The Export of Capital (London: Constable \& Co.).

Horsefield, K., 1969, The International Monetary Fund, 1945-1965: Volume I: Chronicle (Washington DC: International Monetary Fund).

International Monetary Fund, 2005, Evaluation Report: The IMF's Approach to Capital Account Liberalization (Washington DC: International Monetary Fund).

, 2010a, The Fund's Role Regarding Cross-Border Capital Flows (Washington

DC: International Monetary Fund).

, 2010b, The Fund's Mandate-The Legal Framework (Washington DC:

International Monetary Fund).

, 2011a, Recent Themes in Managing Capital Inflows-Cross-Cutting Themes

and Possible Guidelines (Washington DC: International Monetary Fund).

, 2011b, Recent Themes in Managing Capital Inflows-Cross-Cutting Themes

and Possible Guidelines - Supplementary Information (Washington DC: International Monetary Fund).

, 2011c, The Multilateral Aspects of Policies Affecting Capital Flows

(Washington DC: International Monetary Fund).

, 2012a, The Liberalization and Management of Capital Flows: An Institutional View (Washington DC: International Monetary Fund).

,2012b, Liberalizing Capital Flows and Managing Capital Outflows

(Washington DC: International Monetary Fund). 
Ishii, S., and K. Habermeier, 2002, Capital Account Liberalization and Financial Sector Stability, IMF Occasional Paper 211 (Washington DC: International Monetary Fund).

Jeanne, O., and A. Korinek, 2010, "Excessive Volatility in Capital Flows: A Pigouvian Taxation Approach," American Economic Review, 100 (2): 403-407.

Kapstein, E., 1994, Governing the Global Economy: International Finance and the State (Cambridge, MA: Harvard University Press).

Korinek, A., 2011, "The New Economics of Capital Controls," IMF Economic Review, 59 (3): 523-561.

Krugman, P., 1998, “Saving Asia: It's Time to Get Radical,” Fortune, September 7: 7580 .

, 1999, "Capital Control Freaks-How Malaysia Got Away With Economic Heresy,” Slate, September 27.

League of Nations, 1931, Memorandum on International Trade and Balance of Payments 1927-29_Volume II: Balances of International Payments (Geneva: League of Nations).

, 1932, World Economic Survey, 1932 (Geneva: League of Nations).

, 1938, Report on Exchange Control (Geneva: League of Nations).

, 1939, Balance of Payments, 1938 (Geneva: League of Nations).

, 1944, International Currency Experience: Lessons from the Interwar Period (Princeton: Princeton University Press).

, 1948, Balance of Payments, 1939-1945 (Geneva: League of Nations).

Magud, N., and C. Reinhart, 2007, "Capital Controls: An Evaluation," NBER Chapters, in: Capital Controls and Capital Flows in Emerging Economies: Policies, Practices and Consequences (Cambridge, MA: National Bureau of Economic Research): 645-674.

Mills, J., 1922, The Genoa Conference, (London: Hutchinson \& Co.).

Mundell, R., 1963, "Capital Mobility and Stabilization Policy under Fixed and Flexible Exchange Rates," The Canadian Journal of Economics and Political Science, 29 (4): 475 485.

Obstfeld, M., and A. Taylor, 1998, “The Great Depression as a Watershed: International 
Capital Mobility in the Long Run," in The Defining Moment: The Great Depression and the American Economy in the Twentieth Century, eds. M. Bordo, C. Goldin, and E. White, (Chicago: University of Chicago Press): 353-402.

, 2003, "Globalization and Capital Markets," in Globalization in

Historical Perspective, eds. M. Bordo, A. Taylor, and J. Williamson (Chicago: University of Chicago Press): 121-183.

Olson, R., and A. Kim, 2013, "Congress Should Query IMF Support for Capital Controls," The Heritage Foundation Issue Brief No. 3949 (Washington DC: The Heritage Foundation).

Ostry, J., A. Ghosh, K. Habermeier, M. Chamon, M. Qureshi, and D. Reinhardt, 2010, “Capital Inflows: The Role of Controls," IMF Staff Position Note 10/04 (Washington DC: International Monetary Fund).

Ostry, J., A. Ghosh, K. Habermeier, M. Chamon, M. Qureshi, L. Laeven, A. Kokenyne, 2011, “Managing Capital Inflows: What Tools to Use?” IMF Staff Discussion Note 11/06 (Washington DC: International Monetary Fund).

Ostry, J., A. Ghosh, M. Chamon, and M. Qureshi, 2012a, "Tools for Managing FinancialStability Risks from Capital Inflows,” Journal of International Economics, 88 (2): 407-421.

Ostry, J., A. Ghosh, and A. Korinek, 2012b, "Multilateral Aspects of Managing the Capital Account," IMF Staff Discussion Note SDN/12/10 (Washington DC: International Monetary Fund).

Ostry, J., A. Ghosh, and M. Qureshi, 2015, Capital Controls (London: Edward Elgar).

Quinn, D., and C. Inclán, 1997, “The Origins of Financial Openness: A Study of Current and Capital Account Liberalization," American Journal of Political Science, 41: 771-813.

Quinn, D., 2003, "Capital Account Liberalization and Financial Globalization, 1890-1999: a Synoptic View," International Journal of Finance \& Economics, 8 (3): 189-204.

Rodrik, D., 1998," Who Needs Capital-Account Convertibility?" in Should the IMF Pursue Capital-Account Convertibility, Essays in International Finance No. 207 (New Jersey: Princeton University).

Schenk, C., 1998, "The Origins of the Eurodollar Market in London: 1955-1963," Explorations in Economic History, 35: 221-238.

Schularick, M., 2006, “A Tale of Two 'Globalizations': Capital Flows from Rich to Poor in Two Eras of Global Finance," International Journal of Finance \& Economics, 11 (4): 339354. 
Shin, H., and L. Zhao, 2013, "Firms as Surrogate Intermediaries: Evidence from Emerging Economies" mimeo, Princeton University.

Simon, M., 1968, "The Pattern of New British Portfolio Foreign Investment, 1865-191" in The Export of Capital from Britain, 1970-1914, ed. A. R. Hall (London: Methuen \& Co.).

Solomon, R., 1982, The International Monetary System: 1945-1981 (New York: Harper \& Row).

Staley, E., 1935, War and the Private Investor (New York: Doubleday, Doran and Co.)

Stiglitz, J., 2002, “Capital Market Liberalization, Economic Growth, and Instability,” World Development, 28 (6): 1075-1086.

Summers, L., 1998, "Building an International Financial Architecture for the 21st Century," Remarks to the Cato Institute, $16^{\text {th }}$ Annual Monetary Conference, Washington, DC, October 22, 1998.

Viner, J., 1928, "Political Aspects of International Finance," Journal of Business of the University of Chicago, 1 (2): 141-173.

Volcker, P., and T. Gyohten, 1992, Changing Fortunes: The World's Money and the Threat to American Leadership (New York: Three Rivers Press).

Wade, R., and F. Veneroso, 1998, "The Gathering World Slump and the Battle over Capital Controls," New Left Review, No. 231 (September-October): 13-42.

Williamson, J., 1990, "What Washington Means by Policy Reform," in Latin American Adjustment: How Much Has Happened? ed. J. Williamson (Washington DC: Institute of International Economics). 